\title{
Confucius Institute at Universitas Al Azhar, Jakarta The unseen power of China
}

\author{
THUNG JU LAN
}

\begin{abstract}
China's soft power is a difficult concept to measure if the Confucius Institute is the only source relied on. Joseph Nye's concept of soft power puts a strong emphasis on "the power of attraction" as a tool to persuade or "to shape the preferences of others" in the worlds of business and politics. To understand how this soft power - or the Confucius Institute - works, we have to determine the "observable" power of the "intangible" attraction embedded in it. This observable but intangible attraction is assumed to be "embedded" in the language and culture offered by the Institute, namely so-called "shared values". However, without having attended its classes, it is difficult to see which values are being shared with the local students. Despite this handicap, it is very apparent that the image of China itself has acted as an attraction. An attraction to China was visible already, even before the Confucius Institute was established. For Indonesians, China is a big country which has exerted its power there for a long time through its diaspora and/or exports. Therefore, the Confucius Institute is just one of the many forms of Chinese-ness within their purview. Certainly, the Confucius Institute might have assisted in adjusting negative impressions and expelling some of the reservations the Indonesians have about China. Nevertheless, its influence extends to only a limited number of people who are closely engaged with the Institute.
\end{abstract}

THUNG JU LAN is a senior researcher at The Research Centre for Society and Culture - The Indonesian Institute of Sciences (PMB - LIPI). She is interested in the issues of ethnicity and nation-building, particularly in the case of Chinese Indonesians. Her publications include "Chinese in Jakarta after 1965" (in: C. Houston, F. Kurasawa, and A. Watson (eds), Imagined places; The politics of making space, pp. 139-147. La Trobe University, 1998); "Rethinking the 'Chinese' problem" (in: M. Godley and Grayson J. Llyod (eds), Perspectives on the Chinese Indonesians, pp. 163-170. Adelaide: Crawford House Publishing, 2001);"Heterogeneity, politics of ethnicity, and multiculturalism; What is a viable framework for Indonesia?" (Wacana, Journal of the Humanities of Indonesia 13/2 (2011): 209-292); "Contesting the postcolonial legal construction of Chinese Indonesians as 'foreign subjects'” (Asian Ethnicity 13/4 (2012): 373-387). Thung Ju Lan can be contacted at: julan@indo.net.id.

(C) 2017 Faculty of Humanities, Universitas Indonesia

THUNG JU LAN | DOI: 10.17510/wacana.v18i1.576. 
KEYWORDS

Confucius Institute; Universitas Al Azhar; China; soft power; (Chinese) Indonesians.

\section{INTRODUCTION $^{1}$}

The emergence of China as a new global player has been perceived in different ways. Some consider China a "threat" because, as Arvind Subramanian in Eclipse; Living in the shadow of China's economic dominance (2011: xiii) has suggested, "China's dominance [is not only] more imminent, [but also] broader in scope, and much larger in magnitude, than is currently imagined". Others, such as David Shambaugh in China goes global; The partial power (which is published in 2013) believe that, "China's influence is still more broad than deep and that it lacks the influence attributed to a major world power [...] China is a 'partial power'" (as quoted from Schiliró 2013: no pagenumber). But the fact remains that China aims to have a wider and a more significant role in world economic affairs as its investment abroad in raw materials, energy, the nuclear sector and banking and finance has been increasing. The KPMG ${ }^{2}$ s report ${ }^{3}$ points out that, "China's outward direct investment (ODI) overtook inward foreign direct investment (FDI) in 2014, by a narrow margin, making the country a net capital exporter for the first time. China's Ministry of Commerce estimates that the total ODI volume for 2014 stands at around USD 120 billion, a 10 percent rise from USD 108 billion in 2013". Nevertheless, China's image as "the fifth column" seems to persist and works as an obstacle to the concept of China's "peaceful rise". ${ }^{4}$ Geoff Wade (2013), for example, highlights "China's six wars in the next 50 years", indicating that Chinese military action has never been ruled out. Therefore, quoting the Chicago Tribune, Johannes Dragbaek Schmidt (2008: 24) believes that "China is using 'soft power' remedies to nurture 'alliances with many developing countries to solidify its position in the World Trade Organization, flex its muscles on the world stage and act as a counterbalance to US power'".

In the past, the Indonesia-China relationship has not run smoothly for reasons both historical and political: China was accused of being involved in the Communist Party's coup d'etat of 1965 which rocked the country and led to

\footnotetext{
1 This research is part of SEASREP (Southeast Asian Studies Regional Exchange Program) Project on "China's 'soft' footprint in Southeast Asia", 2013-2014.

2 KPMG, operates in 152 countries and have 189,000 people working around the world providing Audit, Tax and Advisory services (https://home.kpmg.com/cn/en/home/about. html, accessed on 22-2-2017). KPMG is the abbreviation of Klynveld Peat Marwick Goerdeler, the initials of its principal founding members, namely Piet Klynveld, William Barclay Peat, James Marwick and Dr. Reinhard Goerdeler (http:/ / kpmgcampus.com/kpmg-family/kpmghistory.shtml, accessed on 22-2-2017).

3 "China outlook 2015" (http://www.kpmg.com/ES/es/Internacionalizacion-KPMG/ Documents/China-Outlook-2015.pdf, accessed on 23-9-2015).

4 "China's peaceful rise; Speeches of Zheng Bijian 1997-2004" (https:/ / www.brookings.edu/ wp-content/uploads/2012/04/20050616bijianlunch.pdf, accessed on 23-9-2015).
} 
the death of hundred thousands of Indonesian people. ${ }^{5}$ The Indonesia-China diplomatic relationship was frozen for about a quarter of a century from 1965 to 1990. However, the increased integration of the Chinese economy into the world market, heralded by its entry into membership in World Trade Organization (WTO) on December 2001, cannot be ignored, because China's trade and investment policies are very likely to have an impact on other developing countries, Indonesia included. Since Indonesia restored its diplomatic relationship with China in 1990, the volume of trade between the two countries has increased significantly. Indonesia's non-oil and gas export to China between 1991 and 1998, for example, increased from around USD 580 million to over USD 1,320 million. ${ }^{6}$ Similarly, Indonesia's imports from China grew from around USD 800 million in 1991 to around USD 1,270 million in 1997, but then fell to USD 980 million in 1998, perhaps on account of the severe economic crisis in Indonesia. ${ }^{7}$ According to Antaranews.com, ${ }^{8}$ during the period January to June 2013, Indonesia`s exports to China touched USD 10.09 billion or 13.5 percent of the country`s total exports. Its imports from China reached USD 14.42 billion. Today, Indonesia under the leadership of President Joko Widodo seems to be taking steps to draw closer to China. As reported by GIV News, in November 2014, Joko Widodo went to Beijing on his first state visit as the President of Indonesia, and he "delivered a memorable presentation at the APEC CEO Summit, opened the Indonesia-China Business Forum, conducted a bilateral talk with Chinese President $X_{i}$ Jinping, and secured twelve economic cooperation MoUs totalling more than IDR 253 trillion (USD 19 billion)". ${ }^{9}$ It was also reported that, "[f]ive months later, President Joko Widodo returned to Beijing and held meetings with the Chinese President Xi Jinping, Chairman of the People's National Congress Zhang Dejiang, and Prime Minister Li Keqiang". Both presidents expressed their willingness to translate the existing relationship into more beneficial cooperation in projects, and Widodo went back home with a "gift of investment commitments totalling IDR 890 trillion (USD 68.4 billion)"..$^{10}$ This closer relationship with China did not come suddenly. In 2005, Indonesia - under the leadership of President Susilo Bambang Yudhoyono (SBY) - and China had agreed to establish a bilateral comprehensive strategic partnership to boost cooperation between the two countries in various fields (namely, industry, infrastructure development in the transportation sector, financial services, tourism, education and the creative industry). This was strengthened during President Xi Jinping's two-

\footnotetext{
5 The MLM Revolutionary Study Group in the US, "The destruction of the Indonesian Communist Party in 1965 and the road not taken", July 2007, (http://www.mlmrsg.com/ attachments/article/75/ The \%20Destruction \%20 of \%20the \%20Indonesian $\% 20$ Communist $\% 20$ Party\%20-\%20revised \%202013.pdf, accessed on 26-9-2015).

Atje and Gaduh 1999.

See Atje and Gaduh 1999.

"Indonesia, China forge comprehensive strategic partnership in various field", Antaranews. com 7 October 2013.

9 Kosasih, Felix Utama, “Is Indonesia shifting orientation to China?”, GIV News 7 May 2015.

10 See footnote 9 .
} 
day state visit to Jakarta in 2013. ${ }^{11}$ In view of this change in the relationship between Indonesia and China, it would be very interesting to figure out how China's "soft power" remedies have worked in Indonesia.

The Confucius Institute has been established by the Chinese in many countries in Asia, Europe, and America and is believed to be the flagship of China's "soft power" which "penetrates" the countries surrounding and far away from China, mainly for the benefit of the Chinese themselves.

As China's economy and exchanges with the world have seen rapid growth, there has also been a sharp increase in the world's demands for Chinese learning. Benefiting from the UK, France, Germany and Spain's experience in promoting their national languages, China began its own exploration through establishing non-profit public institutions which aim to promote Chinese language and culture in foreign countries in 2004: these were given the name the Confucius Institute. ${ }^{12}$

As of Nov 2009, 282 Confucius Institutes and 272 Confucius Classrooms in 88 countries and regions have been established. In Asia, there are 70 Confucius Institutes and 27 Confucius Classrooms. ${ }^{13}$

Through the joint efforts of China and the Confucius Institute host countries in addition to the enthusiasm and active support of people all over the world, by the end of 2010, there have been 322 Confucius Institutes and 369 Confucius Classrooms established in 96 countries. In addition, some 250 institutions from over 50 countries have expressed requirements for establishing Confucius Institutes/Classrooms, amongst them some of the world's top universities. ${ }^{14}$

This year [2014] marks the 10th anniversary of the Confucius Institute, ${ }^{15}$ a network of 353 institutes and 473 classrooms around the world funded by the Chinese government. Some feel that the institutes have done little to change the impression people have of China, yet others feel quite strongly that they have helped craft China's International image, and expand China's soft power. ${ }^{16}$

There have been seven Confucius Institutes established in Indonesia. They are the Jakarta BTIP (Bina Terampil Insan Persada) Kongzi Institute, the Pusat Bahasa Mandarin at Hasanuddin University (哈山努丁大学孔子学院, officially opened on 22 February 2011), the Pusat Bahasa Mandarin at Malang State University (玛琅国立大学孔子学院), the Pusat Bahasa Mandarin at Maranatha Christian University (马达拉塔基督教大学孔子学院, officially opened on January 2011), the Pusat Bahasa Mandarin at Tanjungpura University (丹戎

11 See footnote 8 .

12 “About Confucius Institute Classroom”, Hanban, (http://english.hanban.org/node_10971. htm, accessed on 22-1- 2014).

13 "Confucius Institute in Asia", Confucius Institute, Worldwide, (http:/ / college.chinese.cn/ en/node_3757.htm, accessed on 24-4-2013).

14 "Confucius Institutes in the world", Introduction, (http:/ / college.chinese.cn/en/node_1979. htm, accessed on 24-4-2013).

15 The first Confucius Institute was established in Seoul, South Korea in 2004 (see Michael Ardaiolo 2013b).

16 Melissa Sim 2014. 
布拉大学孔子学院, officially opened on 26 November 2011), the Pusat Bahasa Mandarin at Al Alzhar University (阿拉扎大学孔子学院, officially announced on 8 November 2012), and the Pusat Bahasa Mandarin at Universitas Negeri Surabaya (泗水国立大学孔子学院). With the exception of the BTIP, ${ }^{17}$ the other six university institutes were established by an agreement signed by the representatives of both governments on 28 June 2010. ${ }^{18}$

If we take into the consideration that President SBY had made overtures to China before the Confucius Institute was established in Indonesia, any assertion that the Confucius Institute might have influenced the relationship between China and Indonesia in the first place makes little sense. Even so, we should be aware that, even though the first Confucius Institute (established on 28 September 2007) was attached to the Jakarta BTIP Kongzi Institute, a privately funded Mandarin language course, it was Ambassador Lan Lijun who signed the agreement of co-operation with the Jakarta Chinese Language Teaching Centre (BTIP - 雅加达汉语教学中心孔子学院) on behalf of the Office of Chinese International Language Council (Hanban). Obviously, from China's perspective, the unofficial relationship has a similar significance to that of the official one. He also delivered a speech, saying that the "establishment of the first Confucius Institute in Indonesia is a milestone in the educational cooperation between China and Indonesia". He hoped that the Confucius Institute would "make contributions to the enhancement of the understanding and friendship between the two peoples and strengthen the education and cultural exchanges and cooperation between two sides". Unquestionably, the Confucius Institute signifies the beginning of a "new" level of China-Indonesia friendship, albeit initiated unofficially.

\section{CHINA'S SOFT POWER: A CONCEPTUAL FRAMEWORK}

Recently, we often hear the term "soft power" used to label and question a presumably great influence that one country has over the other(s). China is one of the countries in question. Joseph $\mathrm{Nye}^{19}$ coined the term "soft power" in the late 1980s, but what is "soft power"? The most widely held definition of power as the capacity to do things and to affect the behaviour of others to make those things happen. ${ }^{20}$ Nye himself defined soft power as "the ability to get what you want through attraction rather than through coercion".

Soft power rests on the ability to shape the preferences of others. In the business world, smart executives know that leadership is not just a matter of issuing commands, but also involves leading by example and attracting others to do

17 BTIP contact person is Philip Liwan Pangkey (http://id.china-embassy.org/eng/whjy/ 1xxx/t393549.htm, accessed on 22-1-2014).

18 See http://college.chinese.cn/en/node_3760_2.htm, accessed on 27-6-2013.

19 Joseph S. Nye Jr. is the writer of Soft power; The means to success in world politics (New York: Public Afair, 2005).

20 Tysha Bohorquez reviews Joseph Nye Jr.'s book on the importance of soft power. Published 1 December 2005, (http://www.international.ucla.edu/asia/article/34734, accessed on 24-42013). 
what you want. Similarly, contemporary practices of community-based policing rely on making the police sufficiently friendly and attractive that a community wants to help them achieve shared objectives.

Political leaders have long understood the power that comes from attraction. If I can get you to want to do what I want, then I do not have to use carrots or sticks to make you do it. Soft power is a staple of daily democratic politics. The ability to establish preferences tends to be associated with intangible assets such as an attractive personality, culture, political values and institutions, and policies that are seen as legitimate or having moral authority. If a leader represents values that others want to follow, it will cost less to lead.

Soft power is not merely the same as influence. After all, influence can also rest on the hard power of threats or payments. And soft power is more than just persuasion or the ability to move people by argument, though that is an important part of it. It is also the ability to attract, and attraction often leads to acquiescence. Simply put, in behavioral terms, soft power is attractive power. Soft power resources are the assets that produce such attraction.

If I am persuaded to go along with your purposes without any explicit threat or exchange taking place - in short, if my behavior is determined by an observable but intangible attraction - soft power is at work. Soft power uses a different type of currency - not force, not money - to engender cooperation. It uses an attraction to shared values, and the justness and duty of contributing to the achievement. ${ }^{21}$

The Chinese government (and the Communist Party of China)'s dream of becoming a superpower is not a secret, but the realization that to achieve the goal it must also use "soft-power" to influence the world has dawned only recently. He Qinglian (2009) says that the first government scholar to put forward this view was Zheng Bijian, who wrote an essay entitled "China's peaceful rise to great-power status" in 2005. ${ }^{22}$ The essay was published in Foreign Affairs and was later re-published on the China Daily website under the headline "The new path of China's peaceful rise and US-China relations". ${ }^{23}$ Since then, the idea of China's soft-power has become a hot topic of discussion both inside and outside China. In 2007, President Hu Jintao told the Seventeenth Congress of the Chinese Communist Party that China needed to invest more in its soft power resources. Afterwards, China spent billions of dollars on following his advice, partly through its aid programmes to Africa and Latin America, partly by publicizing high-profile gestures, such as building stadiums (Beijing Olympics 2008 and Shanghai Expo 2010), as well as by founding several hundred Confucius Institutes around the world

21 "The benefits of soft power" by Joseph S. Nye Jr, 8 February 2004. Reproduced with permission of "Soft power and leadership", Compass; A Journal of Leadership (Spring 2004). Compass is published by the Center for Public Leadership, John F. Kennedy School of Government, Harvard University, (http://hbswk.hbs.edu/ archive/4290.html, accessed on 24-4-2013).

22 He Qinglian 2009.

23 He Qinglian 2009. 
to teach its language and culture. ${ }^{24}$

Publicly announced as one of the most appropriate ways to develop cultural exchanges and understandings between China and related countries, the Confucius Institute has played an important role in gathering and establishing a group of local people who welcome and support China's friendly attitude.

Over recent years, the Confucius Institutes' development has been sharp and they have provided scope for people all over the world to learn about Chinese language and culture. In addition they have become a platform for cultural exchanges between China and the world as well as a bridge reinforcing friendship and cooperation between China and the rest of the world and are much welcomed across the globe [...].

Confucius Institutes/Classrooms adopt flexible teaching patterns and adapt to suit local conditions when teaching Chinese language and promoting culture in foreign primary schools, secondary schools, communities and enterprises. In 2009, Confucius Institutes/Classrooms around the world offered 9,000 Chinese courses of a multitude of styles, with a total enrollment of 260,000, a 130,000 strong enrollment increase from the previous year. More than 7,500 cultural exchange activities took place, involving the participation of over 3 million reaching double the participation figures of the corresponding period of the previous year. ${ }^{25}$

Confucius Institutes outside Indonesia have been thoroughly studied. For example, by analysing the details behind the establishment of Confucius Institutes, their organizational mechanism, and their activities in several countries, Zhe Ren (2012: abstract) found that, because of an "insufficiency of cultural content and key concepts which can typify contemporary China", it was "hard to see Confucius Institutes as China's soft power". He argues that, although cultural activities - beside language education - form "the core of the operations that Confucius Institutes engage in overseas", practically "nothing is likely to come to mind right away if they are asked to provide one for Chinese popular culture" (Zhe Ren 2012: 13,19) [something original which is associated with China mainland], not like when they are asked about American popular culture [that is Hollywood), or Japanese popular culture [that is manga or anime]. Joe Tin-yau Lo and Suyan Pan (2014: abstract, 14) who were - because of their analysis of resources, strategies and outcomes - inquisitive about "the dilemmas and predicaments of the [Confucius Institute] project in the exercise of soft power in the globalised age", came to a conclusion that, "China has emphasized resource provision rather than creating appropriate, non-coercive and inter-culturally sensitive strategies to bring about the intended outcomes". Clearly, Lo and Pan have developed a relatively similar argument to that of Zhe Ren, suggesting that "China's lack of attractiveness in cultural diplomacy [...] has something to do with its

24 Joseph S. Nye 2012.

25 "Confucius Institutes in the world", Introduction, (http://college.chinese.cn/en/node_1979. htm, accessed on 24-4-2013). 
deficiency in the national values that appeal to foreign audiences". Others, for instance, Falk Hartig (2010: 11), have also doubted the effectiveness of China's soft power because in his opinion, "Confucius Institutes lack one feature which is essential for institutions like German Goethe-Institute or British Council", namely "the principle of non-intervention by the government", therefore, "when it comes to certain sensitive topics, Confucius Institutes turn quiet or even silent". In his eyes, this trait means that "[Confucius Institutes] don't practice comprehensive and pure cultural diplomacy, but much more a cultural diplomacy with Chinese characteristics"(Hartig 2010: 11). In line with Hartig's point of view, Jennifer Hubbert's study of a Confucius Institutesponsored tour ${ }^{26}$ namely: the Chinese Bridge Summer Camp suggests that, "[that] particular structuring of desire failed to resonate with" what Hubbert referred to as "locally-embedded expectations for identity construction through prefigured notions of authenticity and value".

Framing the role of Confucius Institutes in Indonesia within Nye's definition of soft power is not an easy job, because it is so strongly intertwined with China's power strategy and diplomacy. He Qinglian (2009: no page number) has divided China's diplomacy into three levels: great power diplomacy (with the the US at the core), border diplomacy and resource diplomacy. He argues that China's soft power penetration falls into three different categories as well, namely: economic aid, economic cooperation and cultural penetration. In his opinion, "[f]oreign aid and comprehensive, mutually-penetrating economic relations are the core of China's 'soft power' resources" (He Qinglian 2009). He postulates that, "[T]his, unlike the 'soft power' recognized by the international community, is actually the 'hard power' of economic strength being peddled by China as 'soft power'" (He Qinglian 2009). It means that, under the promise of "incentives", Chinese Communist cultural values and ideas cloaked in Confucius Institutes, have been devised to get the world "to accept a 'Chinese culture' whose flavour has long ago gone bad" (He Qinglian 2009). Undoubtedly, economic and cultural elements are inseparable in China's so-called "soft power". I propose to look at these two factors through an in-depth study of the Confucius Institute at the Universitas Al Azhar. This institute is the only one, among the six Confucius Institutes officially established in Indonesia in 2011, which is located in Jakarta, the capital city.

THE History AND THE LAUNCHing OF THE CONFuCiUs INSTITUTE AT THE Universitas Al AzHar, JAKARTA

The Pusat Bahasa Mandarin (Mandarin Language Centre) at Universitas Al Azhar Jakarta (Illustration 1), ${ }^{27}$ which commenced teaching in 2011, is one example of a Confucius Institute. Interestingly, in Chinese (Mandarin), this

\footnotetext{
26 Jennifer Hubbert 2014.

27 Universitas Al Azhar Indonesia is a private university which was established in 2000. It has six departments, namely: economics, law, social and political sciences, psychology and education, science and technology, and literature, (http:/ / uai.ac.id/, accessed on 10-7-2014).
} 
Pusat Bahasa Mandarin is still called the Kongzi Xueyuan 孔子學院. ${ }^{28}$

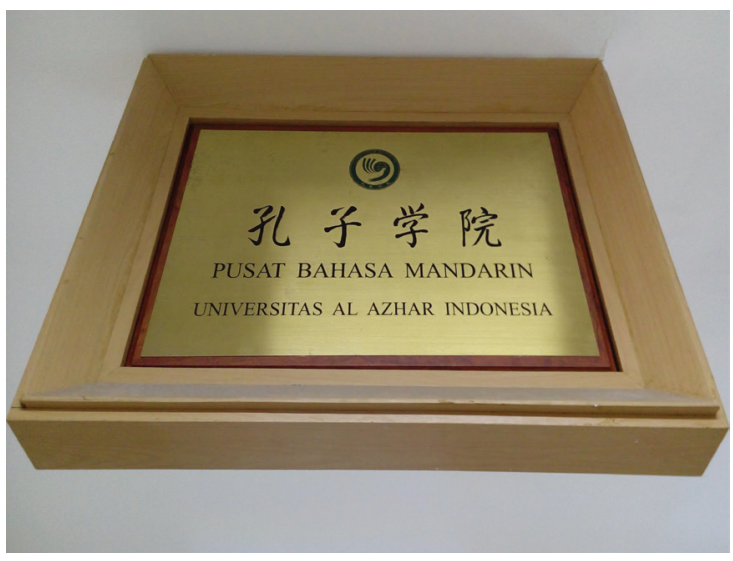

Source: Nabil Forum (third edition, July 2011: 6).

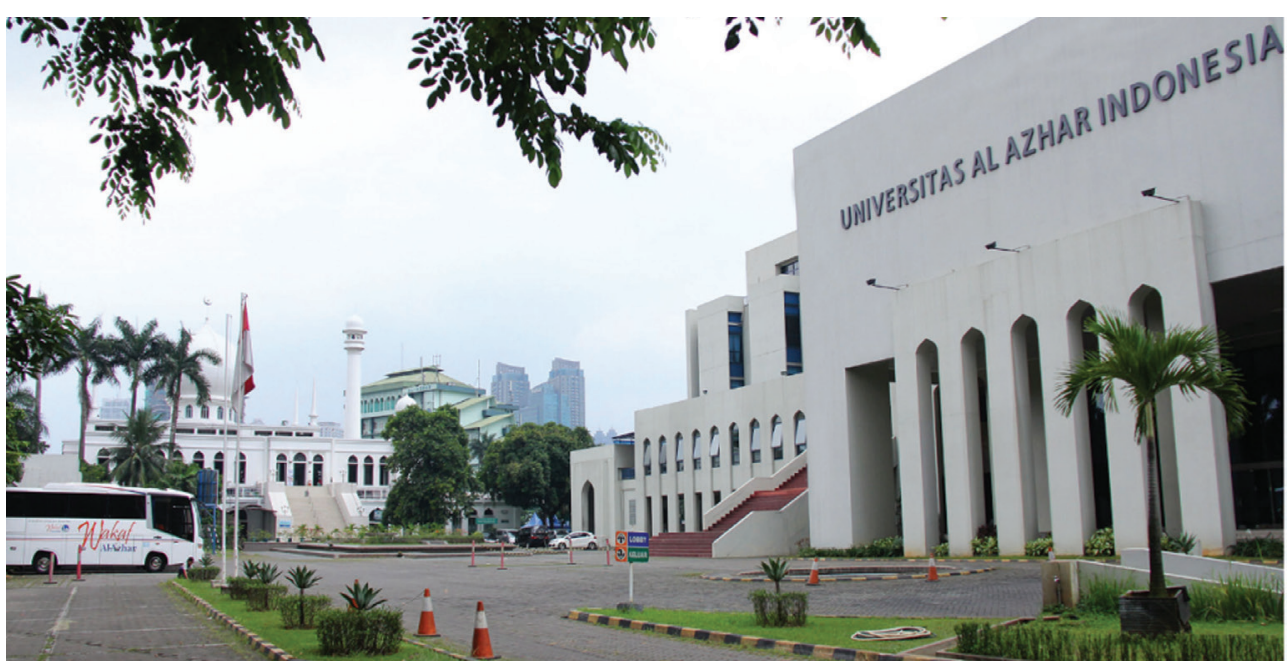

Source: Https:/ / www.google.co.id/search?q=yayasan+Nabil\&source=lnms\&tbm $=$ isch\&sa=X\&ved=0ahUKEwjqs9i99tTSAhWLv48KHQXnDMwQ_AUIBigB\&bi=1 600\&bih=791\#tbs=isz:1\&tbm=isch\&q=universitas+al+azhar+indonesia\&*\&imgr= aqYJjTsXDmZXWM, accessed on 14-3-2017.

Illustration 1. The Confucius Institute at Universitas Al Azhar Indonesia.

The idea to set up the Institute, according to one of the lecturers in the Faculty of Arts at the Universitas Al Azhar who claimed that she was the first Indonesian director of Confucius Institute at the university, came from the Hanban representative or contact person in Indonesia. ${ }^{29}$ However, it has also been said that the Institute was co-established by the Fujian Normal University

28 Http://pbmuai.id.chinesecio.com/.

29 The Hanban is a Beijing-based organization affiliated with China's education ministry. Aubrey Belford (2012) has stated that, "[w]hile nominally non-governmental, the organisation's leadership, including its director, $\mathrm{Xu}$ Lin, is largely comprised of Communist Party officials". 
and the Universitas Al-Azhar. ${ }^{30}$ Another source of information indicated that the Confucius Institute - Kongzi Xueyuan 孔子学院 (Pusat Bahasa Mandarin) at the Universitas Al Azhar, Jakarta was built with philanthropic donations from a number of Chinese Indonesians. What is the true story behind all this information? It is also an interesting journey of discovery to find why the Institute was established in a Muslim-based university, instead of a "nationally known as a multicultural university" institution of higher learning like the Universitas Indonesia.

Searching for relevant written documents, I found a signed agreement of 28 June 2010 which was drawn up between the Office of Chinese Language Council International of China (Hanban 汉办) and the Universitas Al Azhar Indonesia (UAI). ${ }^{31}$ It covers the rights and responsibilities of each institution in the establishment and management of the Pusat Bahasa Mandarin at the Universitas Al Azhar Indonesia. Besides this agreement, the Universitas Al Azhar Indonesia also signed an agreement (2 November 2010), plus an addendum (15 June 2011), to build the office of Confucius Institute with the assistance of the Yayasan Nation Building (Nabil) under the leadership of Eddie Lembong, one of the well-known ethnic Chinese leaders who emerged after the tragic events of May $1998 .^{32}$ This involvement of the Yayasan Nabil is highlighted by an inscribed stone set up in front of the Confucius Institute at the Universitas Al Azhar. The inscription specifies that the building was constructed with a donation from Burhan Uray (Huang Shuang'an; also known as Datuk Seri Bong Swan Ann), a Chinese Indonesian who owns the Djajanti

30 It seems that with the establishment of the Confucius Institute, which is known in Indonesian as the "Pusat Bahasa Mandarin" (Mandarin Language Centre), each Indonesian university enters into a collaboration with a university in China: Universitas Al Azhar Indonesia with Fujian Normal University, Universitas Hasanuddin with Nanchang University, Universitas Negeri Malang with Guangxi Normal University, Universitas Kristen Maranatha with Hebei Normal University, Universitas Negeri Surabaya with Huazhong Normal University, and Universitas Tanjungpura with Northeast Normal University (Kominfonewscenter.com, "Selected News; Pusat Bahasa Mandarin akan dibentuk pada 6 universitas di Indonesia", http:/ / kominfonewscenter. com/ index.php?option=com_content\&view $=$ article\&id=397:pusat-bahasa-mandarin-akandibentuk-pada-6-universitas -di-indonesia\& catid $=36$ : nasional-khusus\&Itemid $=54$, accessed on 27-6-2013).

31 Those documents were uploaded on the Al Azhar website during my first search in 2013, but later I could no longer find them.

32 The so-called tragic event of May 1998 was a series of violent riots all over Indonesia. This was followed by the resignation from power of Suharto (see Pandika, Melissa, "Remembering the May 1998 Riots in Indonesia, http://www.ozy.com/flashback/indonesias-1998-riotsremembered/31732.article, accessed on 19-8-2014). 
Group ${ }^{33}$ through the mediation of the Nabil Foundation..$^{34}$ The Hanban News, on the other hand, reported the signing of an agreement between the Hanban and the Minister of Education and Culture of Indonesia (Illustration 2).

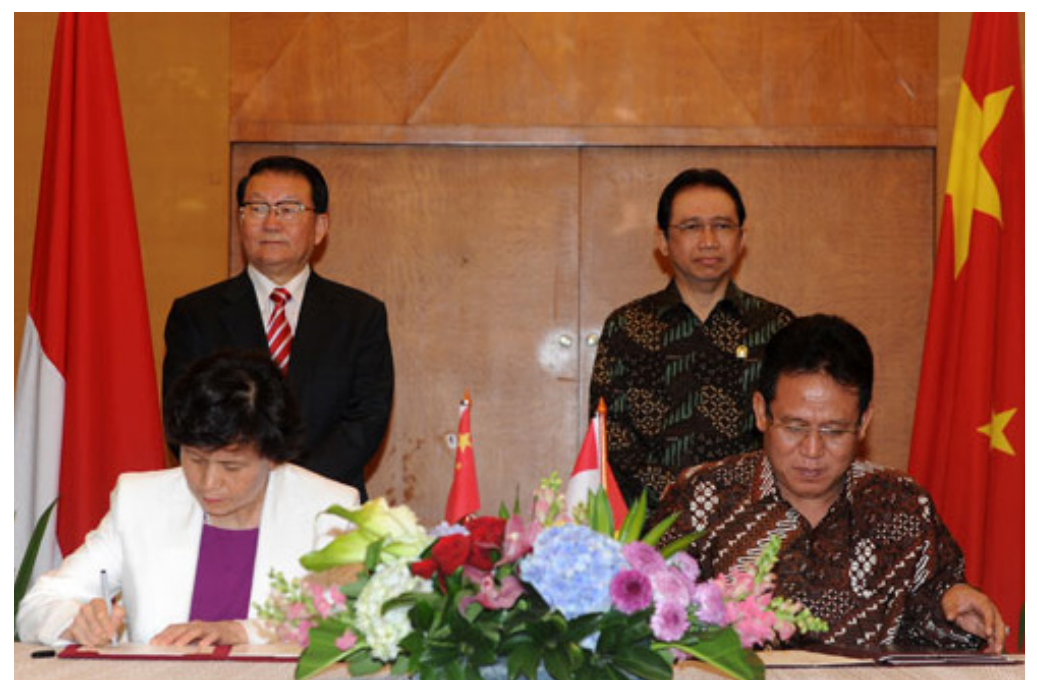

Illustration 2. Signing the Cooperation Agreement by the Director-General of the Hanban, $\mathrm{Xu}$ Lin, and the Representative of the Minister of Education and Culture of Indonesia. Source: Hanban News, Information Centre of Confucius Institute at Universitas Al Azhar Indonesia, 28 April 2012, (http://english.hanban.org/ article/2012-04/28/content_431010.htm, accessed on 27 June 2013).

The Hanban News says that, "[i]n the presence of Mr Li Changchun, a member of the Standing Committee of the Political Bureau of the CPC Central Committee, and Mr Marzuki Alie, Speaker of the Indonesia House of Representatives, Mme Xu Lin, Director-General of the Hanban, China and Mr Syawal Gultom, Representative of the Minister of Education and Culture, Indonesia, signed the Cooperation Agreement on Cultivating Indonesian Chinese Language Teachers in Jakarta in the evening of 26 April 2012". It also said that "[a]ccording to the Agreement, the Hanban and the Ministry of Education and Culture of Indonesia will work together to cultivate 100 Chinese language teachers in three years from 2012 to 2014 and each training

33 As reported by Kompas.com, on Thursday, 8 November 2012, when officially announcing the opening of the office of Pusat Bahasa Mandarin (PBM - Mandarin Language Centre) Universitas Al Azhar Indonesia (UAI) on the UAI campus, the Head of UAI Prof Dr Zuhal also launched a book entitled Burhan Uray berbakti untuk Indonesia. The book was written by Betty Pay, Uray's wife. It tells the lifestory of Burhan Uray who commenced life very poor"bocah penyadap karet" in North Kalimantan, but now at the age of 82 is a successful businessman who has contributed enormously to social and educational foundations, (http://edukasi. kompas.com/read/2012/11/09/12174472/Al.Azhar.Bangun.Pusat.Bahasa.Mandarin, accessed on 27-6-2013; Current Link: http:/ /internasional.kompas.com/read/2012/11/09/12174472/ Al.Azhar.Bangun.Pusat.Bahasa.Mandarin, accessed on 17-5-2015).

34 See Nabil Forum (third edition, July 2011), column on Cooperation, pp. 5-7, (http:/ /www. nabilfoundation.org/ media.php?module=publikasi\&id=186, accessed on 27-6-2013). 
will last six months. Mr Huang Shuang' an (Burhan Uray), a prominent leader of Indonesian Chinese will provide air ticket subsidy for trainees coming to China. The specific work of the Agreement will be jointly undertaken by the Centre for Development and Empowerment of Language Teachers and Education Personnel of the Ministry of Education and Culture of Indonesia, Jakarta Chinese Language Coordination Office and Confucius Institute at Universitas Al Azhar Indonesia".

Obviously, some pretty complicated networking was going on behind the scenes at the establishment of the Confucius Institute at the Universitas Al Azhar. I hope a further study can unravel how many contributions Chinese Indonesians made towards the Institute, their underlying reasons for making the contributions, as well as the extent of their local and regional networking in response to China's "soft power".

My interview of 30 July 2013 with Eddie Lembong, the Chairman of the Nabil Foundation which facilitated the generous involvement of Burhan Uray, the leader of Djajanti Group, in the building of the Confucius Institute at Universitas $\mathrm{Al}$ Azhar, reveals that the motives of these ethnic Chinese leaders are not entirely philanthropic, they also have political overtones. ${ }^{35}$ Eddie Lembong underlined that indigenous Indonesians need to learn about China in order to make them less prejudice towards the Chinese. In order to mark their contribution, these ethnic Chinese leaders asked for the following inscription to be attached to the wall of the Confucius Institute (Illustrations $3 a$ and $3 b)$.

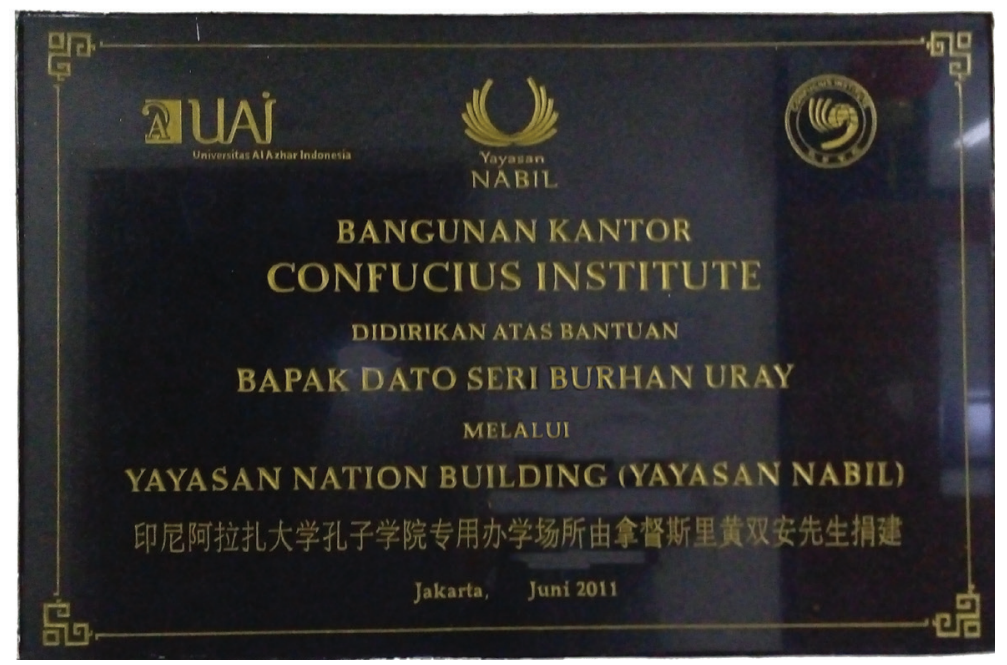

Illustration 3a. The inscription marking Burhan Uray's donation through the Nabil Foundation, June 2011 (photograph by Thung Ju Lan).

35 See also Nabil Forum (third edition, July 2011: 5). In the report about its cooperation with Universitas Al Azhar in the building of the Confucius Institute office, Yayasan Nabil argued that the cooperation was both a direct and indirect implementation of the Yayasan Nabil doctrine of "Cross-Cultural Fertilization" between Indonesian Culture and Chinese Culture. 


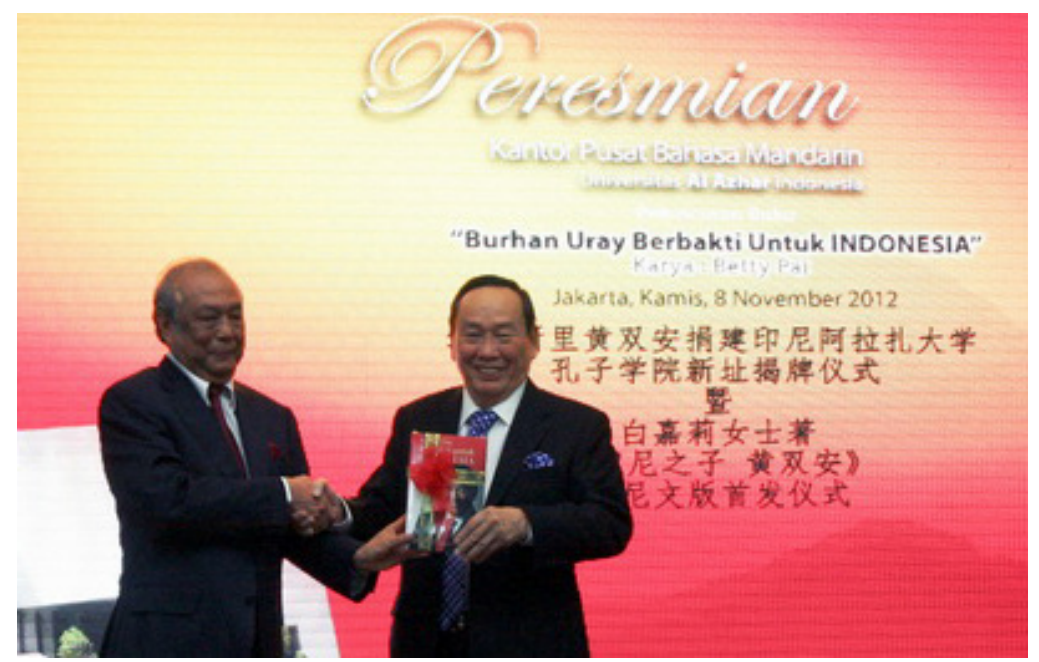

Illustration 3b. At the launching of Confucius Institute office on 8 November 2012, Burhan Uray's autobiography (Burhan Uray berbakti untuk Indonesia) which is written by his wife, Betty Pay, was presented. ${ }^{36}$

In the interview, Eddie Lembong also indicated that it was the Universitas $\mathrm{Al}$ Azhar which had approached him for help in the first place. This story seems to be consistent with what Feri Ansori's said to me during my interview with him as the Indonesian Director of Confucius Institute at Al Azhar on 1 August 2013. He claimed that the Hanban invited the Universitas Al Azhar (UAI) to submit a proposal for cooperation because at that time the UAI already had a working cooperation with the Fujian Normal University. When their proposal was approved by the Hanban, the UAI was faced with the financial problem of finding the funds for the building of Confucius Institute Office, and it was for this reason it approached Eddie Lembong from the Yayasan Nabil. Feri Ansori's explanation might also shed some light on the reason the Confucius Institute was established at the Universitas Al Azhar and not at the Universitas Indonesia. If a previous cooperation with Chinese university in China is a precondition for cooperation with the Hanban, obviously Al Azhar was a better position to accept the invitation. As far as I know, the Chinese Studies Programme at the Universitas of Indonesia has not yet developed any cooperation with a Chinese university in China because most of its lecturers are graduates of Taiwanese universities.

The involvement of the Yayasan Nabil did not finish when the building of the office was completed. In 2013, when the Institute faced a bureaucratic problem in acquiring visas for teachers from China, it also called on Eddie Lembong for help. One of Eddie Lembong's employees at the Nabil Foundation is now a member of what is called the Confucius Institute's task-force. The latest information I have from this task-force shows that the problem they faced was more financial than political, because the Institute was not willing to pay

36 Source: Http:/ / fs.uai.ac.id /?p=655, accessed on 27-1-2014. 
for the teachers' visa application fee which is required under the immigration law of the Republic of Indonesia.

\section{IMAGE CREATION}

Premier Wen Jiabao's visit was considered a big event (Illustration 4). The picture published in the local media ${ }^{37}$ and now displayed on the wall of the Confucius Institute clearly demonstrate that the establishment of this Institute was an undertaking of the Chinese rather than the Indonesian government. The official visit of the Indonesian Ambassador to China, Imron Cotan, and his associates to the Institute took place a year later, on 26 September 2012. ${ }^{38}$ Another interesting fact about Premier Wen Jiabao's visit is the way chosen to describe it, with the caption "Chinese Premier reads Al-Qur'an" ${ }^{39}$ Referring to the Al-Qur'an, Wen called for world peace and tolerance between nations.

"I am pleased to see that the University of Al-Azhar has established a partnership with China's Fujian Normal University and students here have started learning Chinese language. I believe that the university will gain a better understanding of China through close contact with its Chinese counterparts". (Premier Wen Jiabao's speech at the Confucius Institute at the Universitas Al-Azhar.)
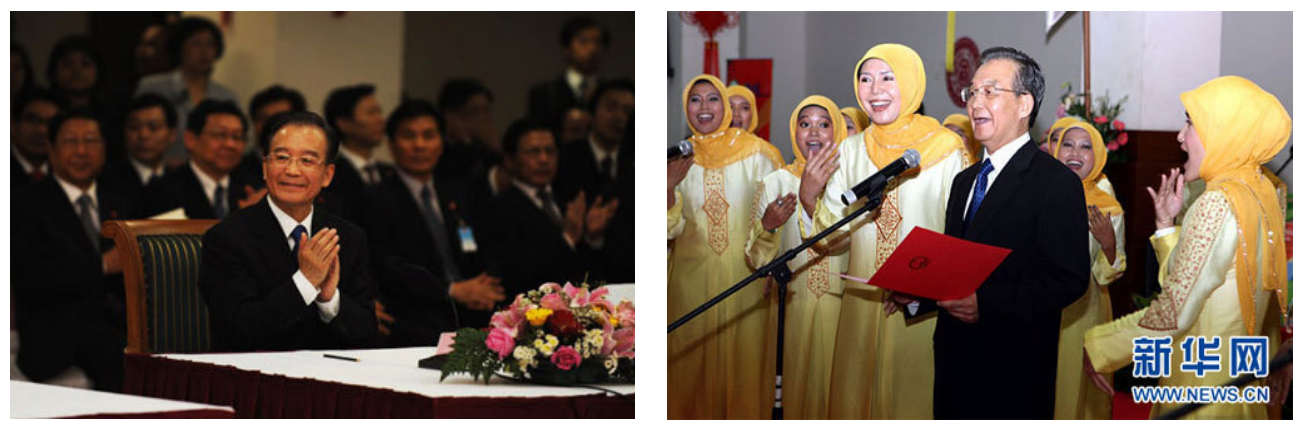

Illustration 4. Premier Wen Jiabao visited the Universitas Al-Azhar on 29 April 2011. ${ }^{40}$

Importantly the visit was made during the same visit during which Premier Wen Jiabao was scheduled to meet President Susilo Bambang Yudhoyono, ${ }^{41}$

37 A similar picture of the event was published in Tribun Pontianak 30 April 2011, (http:/ / issuu.com / tripon/docs/30042011, accessed on 22-1-2014). The event was also mentioned by VIVAnews, (http:/ / detikhots.info/page/4140/), and by CRIonline (2011-04-29 18:03:52 CRI), (http://indonesian. cri.cn/201/2011/04 /29/1s118027.htm, accessed on 22-1-2014).

38 "Indonesian Ambassador to China visits the Confucius Institute at the University of AlAzhar", Hanban News, [Source] Confucius Institute at the University of Al-Azhar [Time] 201209-2913:14:41, (http://english.hanban. org/article/2012-09/29/content_465800.htm, accessed on 22-1-2014).

39 Https:// forum.lowyat.net/topic/1858048/all, accessed on 22-1-2014.

40 Photographed by Yao Dawei, reporter from the Xinhua News Agency, "Highlights of Chinese Premier Wen Jiabao's visit to Confucius Institute at the University of Al-Azhar, Indonesia", (http:/ / english.hanban.org/ article/2011-04/29/content_257863.htm, accessed on 22-1-2014).

41 "Sore ini Presiden SBY terima kunjungan PM Cina", Tempo.co, Politik, 29 April 2011. 
therefore it can assumed that the visit to Al Azhar also fell into the category of diplomacy and bilateral cooperation. This supposition is strengthened by the fact that the "Agreement between the Hanban and the Ministry of Education of the Republic of Indonesia about Cooperation in the Teaching of Chinese" was also recorded in the "Executive Summary" (pp. 52-55 about China), uploaded by the Embassy of Indonesia as part of bilateral cooperation in the field of education. ${ }^{42}$ However, this official agreement, particularly Article 4 no. A.2 and its addendum (see Appendix 1), obviously contradicts the recent problem faced by the Confucius Institute at UAI arising from visa application fee for its teachers imported from China. Was it perhaps a mere copy of what has happened to Confucius Institutes in the US where, under a State Department directive, their Chinese teachers might be forced to return to China? ${ }^{43}$

\section{The Organization of the Confucius Institute at the Universitas Al AzHaR}

Besides the physical fact of classrooms in which Chinese teachers give instruction being set up in the Universitas Al Azhar, and a number of local people and students learning Chinese language, poetry, as well as traditional dances and songs, the Institute does not particularly stand out. ${ }^{44}$ Perhaps it is quite similar to an English teaching classes, albeit more relaxed. However, it is pretty remarkable that at the ninth Confucius Institute Conference held in Xiamen, Fujian Province, on 7 December 2014, the Pusat Bahasa Mandarin at Universitas Al Azhar Indonesia received the "Confucius Institute of the Year" award for its outstanding achievements in the year of 2014. As reported, within the four years since its establishment, the Pusat Bahasa Mandarin at Universitas Al Azhar Indonesia had successfully "set up over ten teaching sites in schools and government departments in Indonesia, including universities in Jakarta, the Jakarta Soekarno-Hatta International Airport, the Indonesian National Police Headquarters ${ }^{45}$ and the Ministry of National Defense".${ }^{46}$ Moreover, in 2014 alone, the Pusat Bahasa Mandarin at Universitas Al Azhar Indonesia also "hosted fifty-one various cultural activities with altogether 29, 870 participants. These included a series of celebrations of the "Confucius Institute Day", commemorative activities on the tenth anniversary of the Confucius Institute, Chinese cultural experience activities, intercultural exchange forums, the

\footnotetext{
42 "Ringkasan Eksekutif", (http://www.embassyofindonesia.org/features/pdf/ Diplomasi_2011.pdf, accessed on 22-1-2014).

43 The directive said that "[A]cademics, under a college's J-1 exchange program, that teach students of elementary or secondary school age are in violation of visa regulations, and said they must return to China by the end of June to reapply for an appropriate program", (see "US targets Confucius Institutes over visas", ChinaDaily.com.cn, 25-5-2012).

${ }_{44}$ However, it is easy to identify the area assigned to the Institute because its Chinese decorative themes (Chinese lampions); see Illustration 5.

45 "The fourth teaching cooperation between the Pusat Bahasa Mandarin at University of Al Azhar and the Language Center of Indonesian National Police Headquarters officially launched", Hanban News, [Source] Confucius Institute at Universitas Al-Azhar, 29-5-2013 14:45:58, (http://english.hanban.org/article/2013-05/29/content_498605.htm, accessed on 27-1-2014).

46 Gu Shihong 2014.
} 
2014 first China Movie Week at the Universitas Al Azhar Indonesia", which, according to $\mathrm{Gu}$ Shihong from www.chinanews.com, "were all popular among the local young people and other residents" ${ }^{47}$ Clearly, there is more than meets the eye to the Confucius Institute at Universitas Al Azhar than its mere physical presence (Illustration 5).

There are two directors who work together to manage Confucius Institute at the Universitas $\mathrm{Al}$ Azhar, a Chinese director and an Indonesian director. Li Qihui, the first Chinese director, served as between 2010 and 2012 (Illustration 6). He established the Confucius Institute's Chinese choir, whose purpose was to kindle Indonesian students' interest in learning Chinese by the singing of ancient Chinese poetry. The choral group has been extremely popular with students. ${ }^{48}$

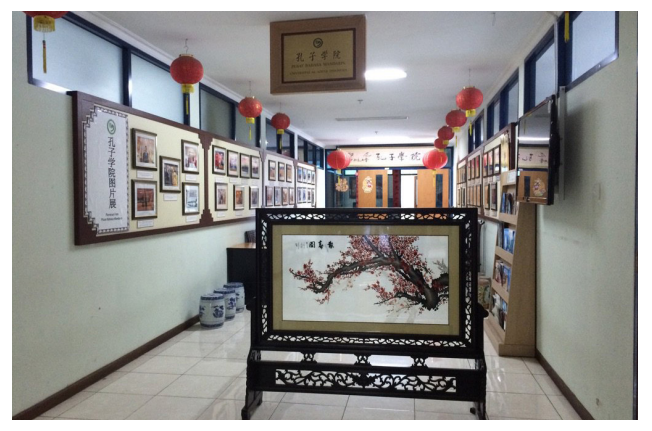

The Chinese lampions. ${ }^{49}$

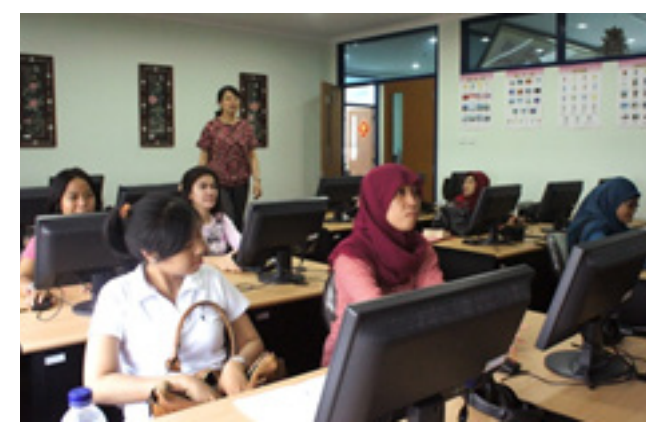

The classroom (photograph by Belford 2012).

Illustration 5. The physical presence of the Confucius Institute at Universitas Al Azhar: the Chinese lampions (left) and the classroom (right).

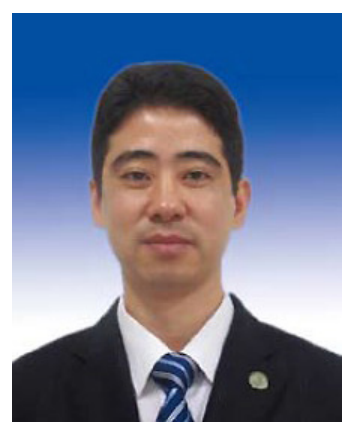

Illustration 6. Li Qihui (2010-2012).50

47 Gu Shihong 2014.

48 "Li Qihui", Hanban - The Sixth Confucius Institute Conference, 12-14 December 2012, Beijing, (http://www.chinese.cn/conference11/article/2011-12/12/content_395456.htm, accessed on 27-6-2013).

49 Source: https://www.google.co.id/search?q=confucius+institute+di+indonesia\&source= lnms\&tbm=isch\&sa $=$ X\&ved=0ahUKEwjdn5jlidXSAhXJpI8KHYEoCg0Q_AUICSgC\&biw $=160$ 0\&bih=791\#tbm=isch\&q=pusat+bahasa+mandarin+universitas+al+azhar+indonesia\&*\&img $\mathrm{rc}=\mathrm{uR} 1 \mathrm{Vw} 7 \mathrm{xx} 5 \mathrm{Za} 0 \mathrm{OM}$.

50 Source: "Li Qihui", Hanban, (http://www.chinese.cn/conference11/article/2011-12/12/ content_395456.htm, accessed on 27-6-2013). 
Li Qihui was well-liked. It was reported that, "[u]nder his [read: Li Qihui] leadership, the Confucius Institute has enjoyed a close cooperation with the Chinese Department of the Universitas Al Azhar, and has selected undergraduate students of the university to study for a master's degree in International Chinese Education in China. He has been actively seeking support from various parties in an effort to increase the financial resources and teaching premises of the Confucius Institute" ${ }^{51}$ There was also a list of what the institute had accomplished. It was said that, within two years of its establishment, the Institute had organized visits to China for secondary and college students to participate in the Chinese Bridge-ASEAN Students' Summer Camp. Likewise, the Institute had successfully organized a "ChinaASEAN Friendship Knowledge Contest" for the Indonesian region. It had also held a Mandarin language competition, known as the Tenth Chinese Bridge for university students, the Fourth Chinese Bridge for senior high school students, as well as the First Chinese Bridge for junior high and primary school students. Student participants in the competitions were asked to sing and read Chinese poems. Utilizing local media resources, the Institute had signed cooperation agreements on Chinese language education with major local television stations. The Institute had also offered Chinese language classes for Indonesian customs officials, at police headquarters ${ }^{52}$ and for airlines. According to one of the Chinese teachers, a statement also confirmed by Feri Ansori (the first and previous Indonesian Director), they offered these Chinese language classes only to those institutions who had signed agreements or $\mathrm{MoU}$ with the Confucius Institute at the Universitas Al Azhar. As the organizer of Li Lanqing Seal Cutting and Calligraphy Exhibition in Indonesia, the Institute offered lectures on seal-cutting and calligraphy, which attracted nearly 1,000 teachers, students, and local residents. ${ }^{53}$ Every month the Institute offered HSK exams at an international standard (Hanyu Shui Ping Kao Shi 汉语水 平考试) to test Mandarin language competence. The HSK exams offered by the Institute were the first computer-based exams in Indonesia. ${ }^{54}$ It should be noted that the Institute charged certain amount money to those who wanted to take the HSK exams. ${ }^{55}$ However, what happened to this money afterwards was not entirely clear.

Li Qihui was replaced by Zhonghua in 2012. Feri Ansori, who has

51 See footnote 50.

52 Http:/ / english.hanban.org/article/2013-05/29/content_498605.htm, accessed on 27-1-2014.

See also footnote 45 .

53 See footnote 55.

54 "Confucius Institute diresmikan di UAI", IndonesiaRayaNews.com 21 November 2012.

55 See "Pusat Bahasa Mandarin Al-Azhar: Jadwal ujian HSK dan HSKK IBT (Berbasis Komputer) Tahun 2014 [...]", (https://www.facebook.com/pusatbahasa.mandarin/ posts/241770559334468, accessed on August 20, 2014). These are the fee charged for each level of HSK and HSKK: HSK Level 1: Rp 125.000; HSK Level 2: Rp 175.000; HSK Level 3: Rp 225.000; HSK Level 4: Rp 300.000; HSK Level 5: Rp 350.000; HSk Level 6: Rp 400.000; HSKK basic: Rp 100.000; HSKK Intermediate: Rp 150.000; HSKK Advance: Rp 200.000. Contact person 0217205089 or Liu Yijiang Laoshi 0838.9441.3428. See also http://beta.kuliahan.org/hsk/, accessed on 20-8-2014. 
served as Indonesian director of Confucius Institute since February 2012, is also a lecturer in Chinese Studies, Faculty of Letters - Universitas Al Azhar Indonesia. He graduated from Yunnan Normal University with a Master's degree in Teaching Chinese as a Foreign Language in 2011. At the moment, he is pursuing further studies at the Beijing Normal University (BNU) under the Confucius Chinese Studies Programme. Today, the Confucius Institute at Universitas Al Azhar has Huang Bin as its Chinese director and Arifin Zain as its Indonesian director. The organization structure and relationship between the Universitas Al Azhar, the Hanban and Fujian Normal University (FNU) is shown in Illustration 7.

Since 2014, the Institute has a new director, Huang Bin 黄涁, and working together with him are six Chinese language teachers from China, two males and four females. Some of these teachers are $\mathrm{PhD}$ graduates, but the majority are still post-graduate students who have a one-year contract only. One teacher does have a permanent appointment; he is a lecturer at FNU who signed a three-year contract with the Confucius Institute at the Universitas Al Azhar (2013-2016). All of them said that they are teaching Chinese language, but their methods can vary from singing to reading. The stated purpose is consistent with what has been noted by Belford (2002), that, "[T] Che Chinese, for their part, are adamant the institutes are apolitical and purely focused on language and culture (see Appendix 2 for the Essence of Chinese culture)" ${ }^{56}$ Perhaps this has been a quite appropriate and effective course of action in the early stages of their establishment, since most of the students could not speak, read or write a fluent Chinese. My observations show that the Chinese teachers at the Confucius Institute, Universitas Al Azhar, can speak only a little Indonesian, ${ }^{57}$ so the senior students will help to translate when junior students do not understand what their teachers are trying to convey. The students taught in this Institute are actually students in the Chinese Studies Programme, Universitas Al Azhar. ${ }^{58}$ Therefore, these teachers from China

56 In a booklet titled "Confucius Institute Online", www.Chinese.cn, the essence of Chinese culture is to include: About China 概览, Cultural Heritage 文化遗产, Customs 民俗, Food 美 食, Tea and Wine 茶与酒，TCM 中医, Travel 旅游, People 人物， Literature 文学, Arts 艺术 and Kung Fu 功夫, (http://www.chinesecio.com/cms/zh-hans/culture/culture-retrieval, accessed on 8-7-2014).

57 This problem has also been observed by Shao Yiwu, a cultural counsellor with the Chinese Embassy in Indonesia. He has written that, "There are mainly three problems facing the development of Confucius Institutes based on what he saw in Indonesia. First, most Chinese language teachers and volunteers sent abroad cannot speak the local language, which inevitably affects their teaching style and method. Second, the work of the teachers and volunteers is assisted by various local Chinese associations, and they are scattered throughout the country, making it hard to form an effective management system. Third, their income is relatively low. Certain teachers and volunteers work and live in poor areas, but are not compensated through higher payments" (see "Confucius Institutes face uphill battle in development", People's Daily Online 31 May 2011.

58 Program Studi Sastra Cina at the Universitas Al Azhar was established in the year 2000, and it began with a diploma level (D3). It moved up to the S1 level in 2005. In its historical background, it is stated that the establishment of the Program Studi Sastra Cina, Universitas Al Azhar was motivated by the desire to become actively involved in global communication and 
are doing the same job as the local ones, the majority of whom are graduates from the Universitas Indonesia.

The structure and relationship

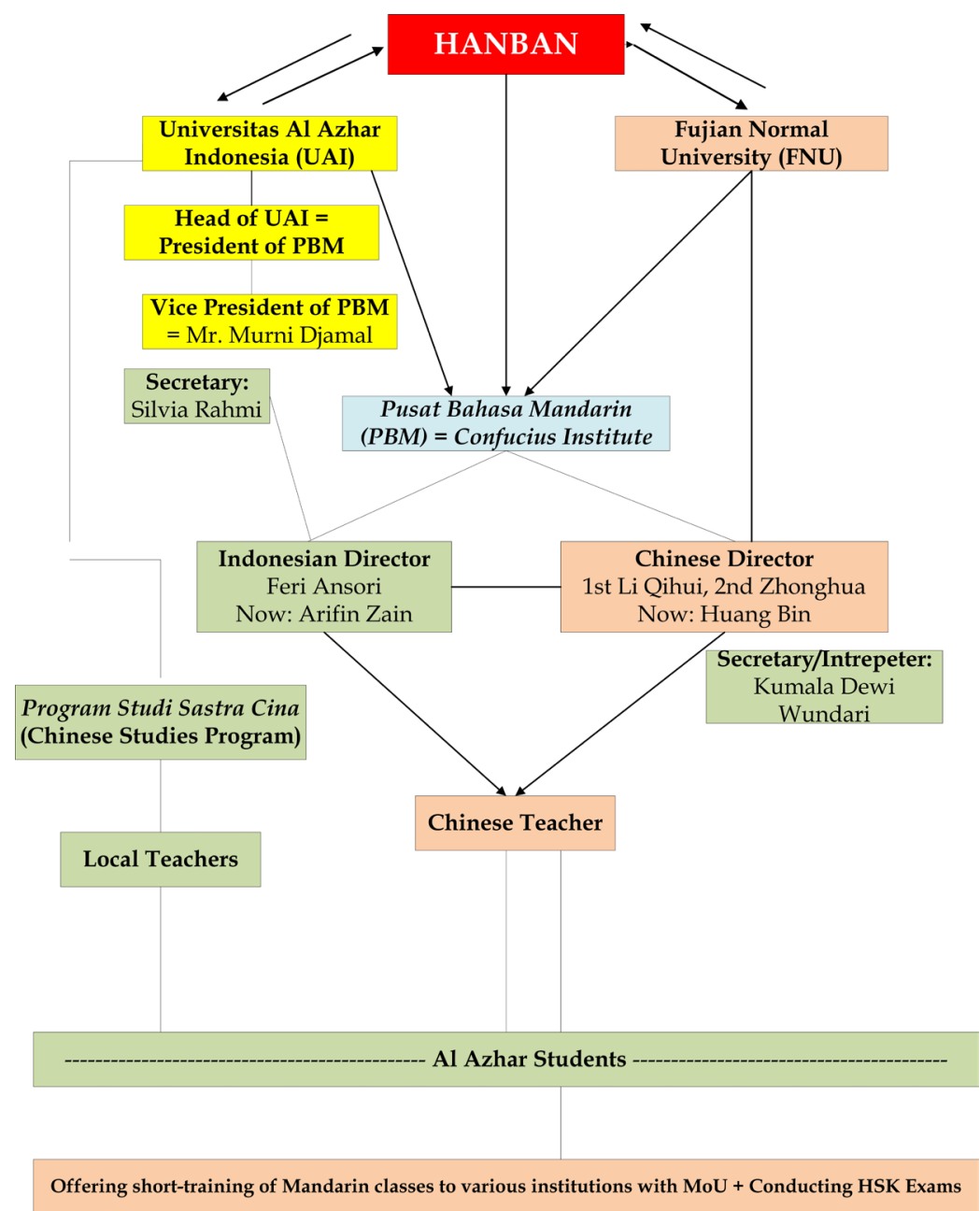

Notes: Mr Murni Djamal previously was the Head of Faculty of Letters, Universitas Al Azhar, Silvia Rahmi is one of Chinese Studies Programme students who is in the final stages of her study, Kumala Dewi Wundari is a FNU graduate, Arifin Zain is from Badan Koordinasi Pembelajaran Bahasa Mandarin (BKPBM) - the Coordination Body for the Learning of Mandarin Language. Silvia and Dewi have recently resigned from PBM or CI, but there has not yet been any replacement.

Illustration 7. The organizational structure and relationship between the Universitas Al Azhar, Hanban, and Fujian Normal University (diagram by the author).

cooperation, particularly with China, which at the moment is at the peak of its development in social, political, cultural and industrial fields. This has been done on the basis of the Prophet Muhammad's teaching which encourages his followers to"seek knowledge even in China"; and, in order to build a national unity and solidarity which includes ethnic Chinese, (http:// fs.uai.ac.id/cina/latar-belakang/, accessed on 26-1-2014). 
One important aspect in the management of cooperation between the FNU, the Hanban and the Universitas Al Azhar, which has been noticed by one of these local teachers ${ }^{59}$ is the difference in styles of management between three Chinese directors of the Confucius Institute at the Universitas Al Azhar. She claims that the first director, Li Qihui, was what she would call a bureaucrat; he was quite good in involving the local teachers in the Confucius Institute's activities. The second director, Zhung Hua, was an academic, so he did not pay much attention to extra-curricular activities, nor was his management style as transparent as that of his predecessor. Huang Bin is a party secretary who has been assigned to FNU, so she thinks that he prefers to go straight to the vice-president of the PBM, Mr Murni Djamal, and does not involve local teachers in any of his plans. A specific function of the Confucius Institute at the Universitas Al Azhar, that is highly appreciated by students and local teachers alike, is the opportunity to go to China for three to six months training, or to pursue further studies at the Universitas Al Azhar's Chinese counterpart in the establishment of the Confucius Institute: the Fujian Normal University. As one of the local teachers suggests, there is also "something special" which attracts students to the Chinese Studies Programme, Universitas Al Azhar. ${ }^{60}$ It is not easy to determine the level of attraction the Confucius Institute exerts on the students, but from the number of students registered at the Programme between 2010-2013, a dramatic increase in the number of students can certainly be seen from directly after the Confucius Institute was established in 2010. Only eight students registered in 2010, but the number jumped to twentythree in 2011; although only nineteen students were active. In 2012 and 2013 the numbers decreased slightly to twenty-one and seventeen students, with sixteen and fifteen active. ${ }^{6}$

\section{Cultural exchange}

As mentioned above, the official name of the Confucius Institute in Indonesia is Pusat Bahasa Mandarin, not "Institut Konfusius", which is actually the more direct translation of its title. Various sources have said that the name Pusat Bahasa Mandarin is used as a substitute for the "Institut Konfusius" because Indonesian government officials had raised some concerns that it might be misinterpreted as a religious institute, since the name Confucius is related to agama Kong $\mathrm{Hu} \mathrm{Cu}$. As a matter of fact, Confucianism in Indonesia is generally known as a Chinese religion, or at least a religious characteristic of Chinese Indonesians. Clearly, the general understanding about Confucianism is quite particular and inadequate, reflecting sparseness of the Indonesian people's knowledge about China.

\footnotetext{
59 Interviewed on 18-7-2014.

60 "Ikatan Guru Mandarin (Ikatguma) Non-Tionghua Indonesia", Facebook, 1 March 2013, (https://www. facebook.com/permalink.php?id=167749926620069\&story_ fbid $=473449359383456$, accessed on 22-1-2014).

61 The information was provided by the Head of Chinese Studies Programme, Santi Cempaka, in an email dated on 25-6-2014.
} 
Although the relationship between China and Indonesia was quite close during the period of $1949-1965,{ }^{62}$ there was a long break in the diplomatic relationship between two countries from 1965 to 1990, after Indonesia unilaterally decided to cut off the relationship. After the normalization of the relationship in July 1990, even though trade between China and Indonesia was quite stable, in other fields of life, with it the picture of China began to change as well. China is now viewed with mixed feelings, fluctuating between admiration and reservation. As stated by the Indonesian Ambassador to China at the reception to celebrate 67th Indonesian Independence Day, held in the ballroom of China World Hotel in Beijing, 17 September 2012, "China is the most important partner for Indonesia" ${ }^{63}$ In 2013, the two countries agreed to expand their bilateral relations into a comprehensive strategic partnership, which will cover a number of sectors: investment, trade, industry, food and energy, and tourism. Among the partnerships approved are cooperation on a China-Indonesia integrated industrial zone, a memorandum of understanding on research and technological development (capacity building and the transfer of technology), as well as agreement for cooperation on space exploration for peaceful purposes. ${ }^{64}$ Nevertheless, the still present reserved attitude towards China is reflected in Josh Chen's writing titled "CAFTA Phobia or Sinophobia?" (2011), which argues against the various opinions blaming China for the flow of Chinese products into Indonesia. ${ }^{65}$

This government to government relationship is also inseparable from the problematic position of Chinese Indonesians in the Indonesian society. Chinese Indonesians are Indonesian citizens, but their loyalty is continually questioned. Conflicts which happened in the past are often raked up again and again. These eventually reach a peak in anti-Chinese sentiments which erupt from time to time. The 1998 May riots were the latest and the biggest disturbances ever to happen in the history of contemporary Indonesia. The role which can be played by this group in China's soft power project might not be as important as it has been assumed. As we have seen, the contribution made by the Chinese community leaders to the Confucius Institute at the Universitas Al Azhar was prompted by a long-shot idealism. They hope that, through communication and cultural exchange, the Confucius Institute can help to lower the level of prejudice and racial intolerance among the indigenous Indonesians.

Unfortunately, during this study, I have not yet been able to attend and observe any events organized by the Confucius Institute, Universitas Al Azhar. The last activity recorded was an international conference of All Confucius Institutes in Asia, held by Universitas Al Azhar at Sultan Hotel on 26-27 May 2014, and attended by thirty-two countries, eighty-four Confucius

\footnotetext{
62 See Liu Hong 2011.

63 "Dubes RI; China, partner terpenting buat Indonesia", detiknews 18 September 2012.

64 "Ini 6 Kesepakatan RI-RRT", Republika.co.id 2 October 2013.

65 Chen, Josh, "CAFTA Phobia atau Sinophobia?", Baltyra.com 18 April 2011, (http:/ / baltyra. com/2011/04/18/ cafta-phobia-atau-sinophobia/, accessed on 27-1-2014).
} 
Institutes, representing a total of 180 participants. ${ }^{66}$ Perhaps, it would be very interesting to observe how the cultural activities and events activated by and exhibited in Confucius Institutes, as Alan H. Yang and Michael Hsiao suggest, ${ }^{67}$ "are facilitated in a politically harmonious manner" by those people in the institutions, who "are educated and cultivated by a selective version of Chinese culture with propaganda contoured and framed by the Chinese government". Even though, it should be noted that Yang and Hsiao also "strongly doubt [...] that the CI-related activities are combining cultural transmission with purposeful, explicit propaganda".

Ardaiolo (2013: 11) himself puts an emphasis on the cultural exchange involved in studying at a Confucius Institute, saying that it is "the strongest determiner of Confucius Institute as an effective tool of Chinese public diplomacy". ${ }^{68}$ He says that, "[...] - teachers are sent abroad by Hanban or the partnering Chinese institution - and this is beneficial to both the students and the teachers. The students enjoy immersive language and culture education, while the teachers are exposed to professional life in a foreign environment. Both parties have the potential to change their own assumptions and opinions of the other's culture as well as their immediate family, friends and acquaintances". My observations have led me to the same conclusion, because the stories brought home by the Indonesian students who have been to China clearly show the positive experience of cultural exchange. ${ }^{69}$ Ardaiola (2013:11) also sees the benefit of the joint-venture model - a Chinese university and a foreign partner, typically another university - for both the Chinese and the foreign universities. His case study shows "how China's intention to promote its language and culture, and in turn boost its soft power, by way of Confucius Institutes is undermined by the reputation of its government", and so he suggests "the [Chinese] government has to be as hands-off as possible" Ardaiolo (2013: 11). But would it be possible to do so when, at least in the Indonesian instance, the Indonesian partner institutions are relying on the Confucius Institute's financial aid, particularly in the form of scholarships? ${ }^{70}$ Critics of China's soft power argue that "the Confucius Institutes fall

\footnotetext{
66 "Konferensi Pusat Bahasa Mandarin di Universitas Al Azhar Indonesia", 30 May 2014, (http://uai.ac.id /2014/05/30/ konfrensi-pusat-bahasa-mandarin-di-universitas-al-azharindonesia/, accessed on 10-7-2014). See also "UAI dukung perkembangan bahasa Mandarin di Indonesia", Jaknewsonline.com 26 May 2014, (http:/ / www.jaknewsonline.com/berita-1245uai-dukung-perkembangan-bahasa-mandarin-di-indonesia.html, accessed on 10-7-2014).

67 Yang and Hsiao 2012.

68 As mentioned before, Falk Hartig (2010: 1, abstract) believes that, Confucius Institutes should be understood as "a tool of cultural diplomacy with Chinese characteristics", because, on the basis of his study on Confucius Institutes in Germany, they "don't do active propaganda [by telling lies and half-truths, b]ut also they don't practice comprehensive and pure cultural diplomacy" (Hartig 2010: 11).

69 See the experience of Mus from Aceh: "Pengalaman pertama di China; Ketika sim-card dan sisir jadi sendok dan garpu", Kompasiana 2 Juni 2013. See also the experience of Arif Rahman Hakim, "Pengalaman di Beijing, China?", 9 September 2011, (http:/ / kimchiofmyheart.blogspot. com/2011/12/ pengalaman-di-beijing-china.html, accessed on 26-1-2014).

70 This situation is based on Feri Ansori's description 1-8-2013.
} 
under the [Communist] party's control", because "intrinsically it's all linked back to the policies of the Chinese Communist Party". Moreover, the Hanban, the coordinator of Confucius Institute worldwide, which is affiliated with China's ministry of education, even though it is said to be a non-government institution, its leaders, including its director, $\mathrm{Xu}$ Lin, are largely composed of Communist Party officials. ${ }^{71}$ However, it is far too difficult to discover how many directives were prearranged by the party; knowledge which would help to determine the direction of the relationship between Confucius Institutes and their host institutions abroad. Looking at the objective which, as Belford suggested, ${ }^{72}$ is to raise China's image abroad, it is still too early to say for sure how effective it has been in the case of Indonesia. Nevertheless, when we observe the development of Chinese language studies in several Indonesian universities, we can see that, among Indonesian students, there is a growing interest in studying China and Chinese language in Indonesia ${ }^{73}$ and in pursuing further study in China. For example, In 2014, UIN (Universitas Islam Negeri, Muslim State University) Ar-Raniry, in Aceh, in cooperation with Wuhan University of Technology (with an agreement signed on 15 April 2014), sent seven of its female students to study in a Master's programme in China. ${ }^{74} \mathrm{On}$ the other hand, Universitas Andalas in Padang is making plans, following in the footsteps of Universitas Sumatera Utara in Medan, to open Chinese Studies Programme. On 4 April 2014, it invited Huang Bin from Confucius Institute at Universitas $\mathrm{Al}$ Azhar to ask for support from the Confucius Institute. ${ }^{75} \mathrm{~A}$ similar intention, to establish a centre of Chinese studies, has been voiced by UIN Syarif Hidayatullah Jakarta ${ }^{76}$ and UNISBANK (Universitas Stikubank) Semarang. ${ }^{77}$ However, this growing popularity of China or of studying about China should not be attributed solely to the Confucius Institute, because the saying of the Prophet "Tuntutlah ilmu walaupun sampai ke negeri China" (pursue knowledge even as far as China), which was publicly repeated by the fourth

71 Belford 2012. See also Ardaiolo 2013, especially pages 10-11.

72 Belford 2012.

73 In relation to this, the Hanban reported that, "In 2012, the six Confucius Institutes in Indonesia provided 163 Chinese language training courses to more than 3,500 students. More than 70 cultural events were held, attracting about 18,000 people. And almost 1,400 people in Indonesia took part in the HSK, the Chinese language proficiency test" (see Zhao Xinying, "Confucius Institutes pick up language learners", Asia Weekly 18 October 2013, http:/ / epaper. chinadailyasia.com/asia-weekly/article-1225.html, accessed on 14-7-2014).

74 Nazarullah, "Lagi, 7 Srikandi UIN Ar-Raniry lanjutkan kuliah ke China", 9 Juli 2014, (http://uin.ar-raniry.ac.id/web/berita/detail/183/superadmin/lagi-7-srikandi-uin-ar-ranirylanjutkan-kuliah-ke-chin, accessed on 10-7-2014).

75 "Upaya melaksanakan mandat mendirikan Jurusan Sastra China", 8 April 2014, (http:/ / www.unand.ac.id/id-/berita/universitas/2776-upaya-melaksanakan-mandat-mendirikanjurusan-sastra-china-, accessed on 10-7-2014).

76 Ahmad Fauzan Sazli, “UIN Jakarta siap dirikan Pusat Kajian China”, 29 April 2014, (http:/ / kabarkampus.com / 2014/04/ uin-jakarta-siap-dirikan-pusat-kajian-china/, accessed on 10-72014).

77 “Unisbank MOU dengan Universitas Guangdong China”, 17 June 2014, (http://www. unisbank.ac.id/berita-terbaru/ unisbank-mou-dengan-universitas-guangdong-china-unisbank. html, accessed on 10-7-2014). 
President of Indonesia, Gus Dur or Abdurrahman Wahid, ${ }^{78}$ when he was alive, has now also become a dictum for many Indonesian Muslims. ${ }^{79}$

China's soft power is a difficult concept to measure on the basis of only experience of the Confucius Institute at the Universitas Al Azhar Indonesia. Attraction to China was already growing before the Confucius Institute was established. In the eyes of Indonesians, China is a big country which has long exerted its power through its diaspora and/or sale of its products. Hence the Confucius Institute is just one of the many forms of Chinese-ness with which they have to deal. Certainly the Confucius Institute might help to improve some negative impressions and dispel some of the reservations Indonesians have about China, but only among a limited number of people who are closely engaged with the institute. In spite of the "Confucius Institute of the Year" award received at December 2014, in general, the Confucius Institute at the Universitas $\mathrm{Al}$ Azhar has not done very much in the last four years; its biggest stumbling block being its own limitation in human resources. Nevertheless, the people in this institute ${ }^{80}$ believe that these four years have been only the first step because, since the beginning, they have been aware of the long road they have to follow before they can achieve real progress with the institute, and they have not given up yet.

\section{CONFucius Institute As CHINA's SOFT POWER}

Joseph Nye's soft power puts a strong emphasis on "the power of attraction" as a tool to persuade or "to shape the preferences of others" in the business and political worlds. This article discusses the Confucius Institute to illustrate what is called China's soft power. To understand how this soft power - or the Confucius Institute - works, we have to determine the "observable" power of "intangible" attraction embedded in this Confucius Institute. This observable but intangible attraction is assumed to be "implanted" in the language and culture offered by the Institute, namely: what are known as "shared values". However, without sitting in on its classes, it is difficult to see what values are being shared with the local students. In the case of the Confucius Institute at the Universitas Al Azhar, it is very apparent that the image of China itself has worked as an attraction. Kumaravadivelu (2012: 4) is right in saying that, "most learners abroad are inclined to see Mandarin as a communicational tool rather than as a cultural carrier. Their interest in Chinese language knowledge appears to be limited to the ability to communicate with the Chinese business community, or to live, study, and work in China. Their main motivation

\footnotetext{
78 "Gusdur - Anak pesantren yang menaklukkan dunia", AnneAhira.com, (http://www. anneahira.com / gusdur. htm, accessed on 10-7-2014). See also "Islam: pribadi dan masyarakat oleh KH Abdurrahman Wahid", NU Online, Taushiyah, 27 June 2014, (http:/ / nu.or.id/a,publicm,dinamic-s,detail-ids,6-id,52909-lang,id-c,taushiyah-t,Islam++ Pribadi+dan+Masyarakat-. phpx, accessed on 10-7-2014).

79 See Dini, Bina Izzatu, "Seek knowledge, even if you have to go to China for it", Perhimpunan Pelajar Indonesia Tiongkok, 24 December 2013, (http:/ / www.ppitiongkok.org/ halkomentar-165-87.html, accessed on 18-7-2014).

80 Interviewed on 18-7-2014.
} 
is to benefit from Chinese economic expansion. Their interest in Chinese cultural-knowledge is focused on cultural awareness, rather than cultural assimilation or cultural accommodation". Obviously, for these people - the Indonesians included - the Confucius Institute provides a channel by which to know China, to understand China and the Chinese people, and perhaps to penetrate China. Therefore, as long as China's impressive economic and scientific achievements continue to attract people's attention, I think the Confucius Institute - particularly Confucius Institute at Al Azhar which is located in the capital city of Indonesia, Jakarta - will continue to have a "strategic significance" in enhancing friendship and mutual understanding between China and other nations and to some extent, in elevating China's influence in the international community.

\section{REFERENCES}

“About Confucius Institute Classroom", Hanban. [Retrieved from: http:// english. hanban.org/node_10971.htm, accessed on 22-1- 2014].

Ardaiolo, Michael. 2013. “Are Confucius Institutes Chinese public diplomacy tools or Trojan Horse", Exchange 17 August. [Retrieved from: http:// www.exchange diplomacy.com/are-confucius-institutes-chinese-publicdiplomacy-tools-or-trojan-hourse, accessed on 19-7-2014].

This website is no longer accessible; A similar article by the same write come up in the Public Diplomat with a slighltly different title "Cultural Diplomacy or Trojan Horse?" [Retrieved from: http:/ thepublicdiplomat. com/2013/09/01/confucius-institutes-chinese-public-diplomacy-toolsor-trojan-horses/, accessed on 26 February 2017].

Atje, Raymond and Arya B. Gaduh. 1999. "Indonesia-China economic relations; An Indonesian perspective". Paper presented at the ChinaASEAN Research Institutes Roundtable 1999, organized by the Centre of Asian Studies, the Hong Kong University, 16-18 September. [Retrieved from: http:// comp.uark.edu/ gaduh/papers/wpe 052.pdf, accessed on 23-9-2015].

Belford, Aubrey. 2012. "Communists in the Classroom?", The Global Mail 1 March. [Retreived from: http://www.theglobalmail.org/feature/ communists-in-the-classroom /97/, accessed on 27-6-2013].

Bohorquez, Tysha. 2005. "[Review of] Soft power; The means to success in world politics (Joseph S. Nye, New York: Public Affair, 2005)". [Reviews Joseph Nye Jr.'s book on the importance of soft power; Retrieved from: http:/ / www.international.ucla. edu/asia/article/34734, accessed on 24-4-2013].

“China's peaceful rise; Speeches of Zheng Bijian 1997-2004". [Retrieved from: https://www. brookings.edu/wp-content/uploads/2012/04/20050616b ijianlunch.pdf, accessed on 23-9-2015].

"China outlook 2015". [Retrieved from: http://www.kpmg.com/ES/es/ Internacionalizacion-KPMG/Documents/China-Outlook-2015.pdf, accessed on 23-9-2015]. 
"Confucius Institutes face uphill battle in development", People's Daily Online 31 May 2011. [Retrieved from: http://english.people.com. cn/90001/90782/90873/7396218.html, accessed on 14-7-2014].

"Confucius Institute diresmikan di UAI", IndonesiaRayaNews.com 21 November 2012. [Retrieved from: http://www.indonesiarayanews.com/news/ komunitas/11-21-2012-20-17/confucius-institute-diresmikan-di-uai, accessed on 22-1-2014].

"Confucius Institute in Asia", Confucius Institute, Worldwide. [Retrieved from: http://college.chinese.cn /en/node_3757.htm, accessed on 24-42013].

"Confucius Institutes in the world", Introduction. [Retrieved from: http:// college. chinese.cn /en/node_1979.htm, accessed on 24-4-2013].

Dini, Bina Izzatu. 2013. “Seek knowledge, even if you have to go to China for it", Perhimpunan Pelajar Indonesia Tiongkok 24 December 2013. [Retrieved from: http://www. ppitiongkok.org/2014/08/08/seek-knowledge-evenif-you-have-to-go-to-china-for-it/, accessed on 08-08-2014].

"Dubes RI: China, partner terpenting buat Indonesia", detiknews 18 September 2012. [Retrieved from: http:/ / news.detik.com/read/2012/09/18/060242 /2023323/10/ dubes-ri-china-partner-terpenting-buat-indonesia, accessed on 27-1-2014].

Gu, Shihong. 2014. "Pusat Bahasa Mandarin at University of Al Azhar Indonesia receives 'Confucius Institute of the Year' award", wwww. chinanews.com 9 December 2014. [Retrieved from: http:/ / www.chinese. cn/hanban_en/article/2015-01/08/content_569680.htm, accessed on 25-9-2015].

"Gusdur - Anak pesantren yang menaklukkan dunia", AnneAhira.com. [Retrieved from: http://www.anneahira.com /gusdur. htm, accessed on 10-7-2014].

Hartig, Falk. 2010. “Confusion about Confucius Institutes; Soft power push or conspiracy? A case study of Confucius Institutes in Germany". [Retrieved from: http://asaa.asn.au/ASAA2010 / reviewed_papers/Hartig-Falk. pdf, accessed on 14-7-2014. Current Link: http:// citeseerx.ist.psu.edu/ viewdoc/download?doi= 10.1.1.458.49\&rep=rep1\&type=pdf, accessed on 17-5-2015].

He Qinglian. 2009. "'Soft power' with Chinese characteristics is changing the world", China Rights Forum No. 4. [Retrieved from: http:/ / www. hrichina. org/en/content/3175, accessed on 24-5-2013].

Hubbert, Jennifer. 2014. "Authenticating the nation; Confucius Institutes and soft-power", in: Zaharna, Jennifer Hubbert, and Falk Hartig (eds), Confucius Institutes and the globalization of China's soft power, pp. 33-46. Los Angeles: Figueroa Press. [Retrieved from: https:/ / uscpublicdiplomacy.org/sites/ uscpublicdiplomacy.org/files/useruploads/u25044/Confucius $\% 20$ Institutes\%20v2\%20(1).pdf, accessed on 28-9-2015.]

"Ikatan Guru Mandarin (Ikatguma) Non-Tionghua Indonesia", Facebook 1 March 2013. [Retrieved from: https://www.facebook.com/permalink. 
php?id=167749926620069\&story_fbid=473449359383456, accessed on 22-12014].

"Indonesian Ambassador to China visits the Confucius Institute at the University of Al-Azhar", Hanban News, [Source] Confucius Institute at the University of Al-Azhar [Time] 29-09-2012 13:14:41. [Retrieved from: http:/ /english.hanban.org/ article/2012-09/29/ content_ 465800. $\mathrm{htm}$, accessed on 22-1-2014].

"Indonesia, China forge comprehensive strategic partnership in various field", Antaranews.com, 7 Oktober 2013. [Retrieved from: http://www. antaranews.com/ en/news/91035/indonesia-china-forge-comprehensivestrategic-partnership-in-various-field, accessed on 23-9-2015].

"Ini 6 Kesepakatan RI-RRT", Republika.co.id 2 October 2013. [Retrieved from: http:/ / berita.plasa.msn.com/internasional/republika/ini-6-kesepakatanri-rrt, accessed on 26-1-2014].

"Islam; Pribadi dan masyarakat oleh KH Abdurrahman Wahid", NU Online, Taushiyah, 27 June 2014. [Retrieved from: http://nu.or.id/a,publicm,dinamic-s, detail-ids,6-id, 52909-lang,id-c,taushiyah-t,Islam++ Pribadi+dan+Masyarakat-.phpx, accessed on 10-7-2014].

"Konferensi Pusat Bahasa Mandarin di Universitas Al Azhar Indonesia", 30 May 2014. [Retrieved from: http:/ / uai.ac.id /2014/05/30/konfrensipusat-bahasa-mandarin-di-universitas-al-azhar-indonesia/, accessed on 10-7-2014].

Kosasih, Felix Utama. 2015. "Is Indonesia shifting orientation to China?", GIV News 7 May 2015. [Retrieved from: http:/ / www.globalindonesianvoices. com/20605/is-indonesia-shifting-orientation-to-china/, accessed on 239-2015].

Kumaravadivelu, B. 2012. "Global Mandarin; Promoting Chinese language and culture in an age of globalization", Journal of Chinese Language Studies Vol. 8 (December 2012): 1-7. [Retrieved from: http:/ / www.bkumaravadivelu. com/articles\%20in\%20pdfs/ $2012 \% 20$ Global\%20Mandarin.pdf, accessed on 20-8-2014].

"Li Qihui", Hanban, The 6th Confucius Institute Conference, 12-14 December 2011, Beijing. [Retrieved from: http://chinese.cn/conference11/ article/2011-12/12/content_395456.htm, accessed on 27-6-2013].

Liu Hong. 2011. China and the shaping of Indonesia, 1949-1965. Singapore: NUS in association with Kyoto University Press.

Lo, Joe Tin-yau and Suyan Pan. 2014. "Confucius Institutes and China's soft power; Practices and paradoxes", Compare; A Journal of Comparative and International Education Vol. 46/6: 512-532. [DOI: 10.1080/03057925.2014.916185. Routledge, downloaded by Hongkong Institute of Education, 3 June 2014; Retrieved from: https:/ / www. ied.edu. hk/flass/fas_upload/userfiles/pdf/Confucius\%20Institutes\%20and $\% 20$ Chinas\%20Soft\%20Power.pdf, accessed on 28-9-2015].

Nazarullah. 2014. "Lagi, 7 Srikandi UIN Ar-Raniry lanjutkan kuliah ke China”, 9 Juli 2014. [Retrieved from: http://uin.ar-raniry.ac.id/web/berita/ 
detail/183/superadmin/lagi-7-srikandi-uin-ar-raniry-lanjutkan-kuliahke-chin, accessed on 10-7-2014].

Nye, Joseph S. Jr. 2004. "The benefits of soft power", 8 February. Reproduced with permission of "Soft power and leadership", Compass; A Journal of Leadership (Spring 2004). [Retrieved from: http://hbswk.hbs.edu/ archive/4290.html, accessed on 24-4-2013].

Nye, Joseph S. Jr. 2005. Soft power; The means to success in world politics. New York: Public Affair.

Nye, Joseph S. Jr. 2012. “China's soft power deficit”. [Retrieved from: http:/ / www.wsj.com/articles/SB1000142405270230445110457738992309867884 2, accessed on 17-5-2013].

Pandika, Melissa, "Remembering the May 1998 riots in Indonesia". [Retrieved from: http://www.ozy.com/flashback/indonesias-1998-riotsremembered/31732.article, accessed on 19-8-2014].

"Pengalaman pertama di China; Ketika sim-card dan sisir jadi sendok dan garpu", Kompasiana, 2 Juni 2013. [Retrieved from: http://wisata. kompasiana.com/jalan-jalan/2013/06/02/pengalaman-pertama-dichina-ketika-sim-card-dan-sisir-jadi-sendok-dan-garpu-565273.html, accessed on 26-1-2014].

“Pengalaman di Beijing, China?", 9 September 2011. [Retrieved from: http:// kimchiofmyheart.blogspot.com/2011/12/ pengalaman-di-beijing-china. html, accessed on 26-1-2014].

"Ringkasan Eksekutif". [Retrieved from: http://www.embassyofindonesia. org/features/pdf/Diplomasi_2011.pdf, accessed on 22-1-2014].

Sazli, Ahmad Fauzan. 2014. "UIN Jakarta siap dirikan Pusat Kajian China”, 29 April. [Retrieved from: http:/ / kabarkampus.com /2014/04/uin-jakartasiap-dirikan-pusat-kajian-china/, accessed on 10-7-2014].

Schiliró, Daniele. 2013. "China's new role in the global arena". A revised version of the speech given at the Horasis Global China Business Meeting, 10-11 November, The Hague, The Netherlands. [Retrieved from: http://www. horasis.org/press_releases_all_74.php, accessed on 23-9-2015].

Schmidt, Johannes Dragbaek. 2008. "China's soft power diplomacy in Southeast Asia", The Copenhagen Journal of Asian Studies 26/1: 22-49.

Sim, Melissa. 2014. "Confucius Institutes; Expanding China's soft power", The Straits Times Asia Report 9 February 2014. [Retrieved from: http://www. stasiareport.com/the-big-story/asia-report/china/story/confuciusinstitutes-expanding-chinas-soft-power-20140209, accessed on 18-7-2014].

"Sore ini Presiden SBY terima kunjungan PM Cina, Tempo.co, Politik, 29 April 2011 11:18 WIB. [Retrieved from: http://www.tempo.co/ read/news/2011/04/29/ 078330912/Sore-Ini-Presiden-SBY-TerimaKunjungan-PM-Cina, accessed on 22-1-2014].

Subramanian, Arvind. 2011. Eclipse; Living in the shadow of China's economic dominance. Washington D.C.: Peterson Institute for International Economics.

"The fourth teaching cooperation between the Pusat Bahasa Mandarin at University of Al Azhar and the Language Center of Indonesian National 
Police Headquarters officially launched", Hanban News, [Source] University of Al Azhar [Time] 29-05-2013 14:45:58. [Retrieved from: http://english. hanban.org/article/2013-05/29/content_498605.htm, accessed on 27-12014].

The MLM Revolutionary Study Group in the U.S. 2007. "The destruction of the Indonesian Communist Party in 1965 and the road not taken", July 2007. [Retrieved from: http://www.mlmrsg.com/attachments/article/75/ The \% 20Destruction $\%$ 20 of \% 20the \%20Indonesian \%20Communist $\% 20$ Party\%20-\%20revised\%202013.pdf, accessed on 26-9-2015].

"UAI dukung perkembangan bahasa Mandarin di Indonesia", Jaknewsonline. com 26 May 2014. [Retrieved from: http://www.jaknewsonline.com/ berita-1245-uai-dukung-perkembangan-bahasa-mandarin-di-indonesia. $\mathrm{html}$, accessed on 10-7-2014].

"Unisbank MOU dengan Universitas Guangdong China", 17 June 2014. [Retrieved from: http://www.unisbank.ac.id/berita-terbaru/unisbankmou-dengan-universitas-guangdong-china-unisbank.html, accessed on 10-7-2014].

"Upaya melaksanakan mandat mendirikan Jurusan Sastra China", 8 April 2014. [Retrieved from: http://www.unand.ac.id/id-/berita/universitas/2776upaya-melaksanakan-mandat-mendirikan-jurusan-sastra-china-, accessed on 10-7-2014].

"US targets Confucius Institutes over visas", ChinaDaily.com.cn, 25 Mei 2012. [Retrieved from: http://www.chinadaily.com.cn/china/2012-05/25/ content_15382529.htm, accessed on 27-1-2014].

Wade, Geoff. 2013. "China's six wars in the next 50 years", The Strategist 26 November.

Yang, Alan H. and Michael Hsiao. 2012. "Confucius Institutes and the questions of China's soft power diplomacy", China Brief Vol.12/13 (6 July). [Retrieved from: http://www.jamestown.org/programs/chinabrief/ single $/$ ?tx_ttnews[tt_news] $=39592 \& t x \_t$ tnews $[$ backPid] $=25 \& \mathrm{cHash}=139 \mathrm{ec}$ a661387da2154adec9733bd87c1\#.U8OQ9kAqZqw, accessed on 14-7-2014].

Yao Dawei, "Highlights of Chinese Premier Wen Jiabao's visit to Confucius Institute at the University of Al-Azhar, Indonesia", Xinhua News Agency. [Retrieved from: http://english. hanban.org/article/2011-04/29/ content_257863.htm, accessed on 22-1-2014].

Zhao Xinying. 2013. "Confucius Institutes pick up language learners", Asia Weekly 18 October. [Retrieved from: http:/ / epaper.chinadailyasia.com/ asia-weekly/article-1225.html, accessed on 14-7-2014].

Zhe, Ren. 2012.“The Confucius Institutes and China's soft power”, IDE Discussion Paper No. 330, Institute of Developing Economies, March 2012. [Retrieved from: https://ir.ide.go.jp/dspace/bitstream/2344/1119/1/ ARRIDE_Discussion_No.330_ren.pdf, accessed on 14-7-2014].

Zheng, Bijian. 2005. "China's peaceful rise to great-power status". [Retrieved from: https://www.foreignaffairs.com/articles/asia/2005-09-01/chinaspeaceful-rise-great- power-status, accessed on 24-5-2013]. 


\title{
APPENDIX 1
}

\author{
ARRANGEMENT \\ BETWEEN \\ DIRECTORATE GENERAL OF QUALITY IMPROVEMENT \\ FOR TEACHERS AND EDUCATION PERSONNEL \\ MINISTRY OF NATIONAL EDUCATION OF \\ THE REPUBLIC OF INDONESIA \\ AND \\ THE OFFICE OF CHINESE LANGUAGE \\ COUNCIL INTERNATIONAL OF \\ THE PEOPLE'S REPUBLIC OF CHINA \\ CONCERNING \\ CHINESE LANGUAGE TEACHING
}

The Directorate General of Quality Improvement for Teacher and Education Personnel, Ministry of National Education of the Republic of Indonesia and the Office of Chinese Language Council International of the People's Republic of China, hereinafter referred to as "the Parties";

DESIRIING to promote the cooperation in the field of education, particularly in development of Chinese Language capacity of Indonesian teachers and education personnel;

REFERRING to the Agreement between the Government of the Republic of Indonesia and the Government of the People's Republic of China on Cultural Cooperation, signed at Jakarta on November 7, 2001;

PURSUANT to the prevailing laws and regulations of the respective countries;

HAVE REACHED AN ARRANGEMENT as follows:

\section{ARTICLE 1}

OBJECTIVE

The objective of the cooperation is to expand Chinese language teaching in Indonesia.

\section{ARTICLE 2}

\section{SCOPE OF COOPERATION}

In view of effective achievement of the objective, the cooperation to be undertaken by this Arrangement shall cover the following areas:

1. Provision of Chinese language teachers in Indonesia;

2. Professional in-service teacher training for Indonesian teachers of the Chinese language;

3. Provision of teaching materials;

4. Exchange of information on Chinese language teaching; and

5. Visits to China by Indonesian teachers and education personnel. 
ARTICLE 3

MECHANISM

The nominated Chinese Language Teachers shall be approved by the Government of the Republic of Indonesia.

\section{ARTICLE 4}

\section{RIGHTS AND OBLIGATIONS OF THE PARTIES}

A. INDONESIAN SIDE

1. To be responsible for organizing the sending of teachers and education personnel to China;

2. To assist the issuance of visa and stay permit for the approved Chinese language teachers;

3. To be responsible for the assignment of the Chinese language teachers to the selected schools;

4. To guarantee that the teaching hours of the Chinese language teachers are equal to those of the Indonesian teachers; and

5. To provide every Chinese language teacher with proper accommodation and health insurance.

B. CHINESE SIDE

1. To be responsible for processing application, selection, training and dispatching of Chinese language teachers to Indonesia;

2. To conduct in-service teacher training on the teaching of the Chinese language as a foreign language in Indonesia;

3. To assist the arrangement of visas for the Chinese language teachers;

4. To ensure that the Chinese language teachers meet the requirements agreed by the Parties;

5. To ensure that the Chinese language teachers have basic understanding of Indonesian language and culture;

6. To provide monthly living allowance and round-trip international airfare to Chinese language teachers;

7. To provide information on Chinese language teaching;

8. To provide samples of the agreed teaching materials prior to the dispatch of such materials.

\section{ARTICLE 5}

REGULATION OF AC.TIVITIES OF PERSONNEL

Teachers and education personnel from China dispatched to Indonesia and those from Indonesia dispatched to China shall all:

a. Observe, respect and comply with the laws and reguiations and the policies of the Government of the other side;

b. Respect the customs, traditions, and religions of the local community;

c. Refrain from conducting any activities other than those agreed upon by the parties. 
Either Party may request in writing for the amendment of this Arrangement. Such amendment agreed upon by the Parties shall come into effect on such date as will be determined by the Parties.

\section{ARTICLE 7}

\section{SETTLEMENT OF DISPUTE}

Any dispute concerning the implementation of this Arrangement shall be settled amicably through consultation or negotiations between the Parties.

\section{ARTICLE 8 \\ ENTRY INTO FORCE, DURATION AND TERMINATION}

This Arrangement shall enter into force on the date of signing. It shall be valid for 5 (five) years from 2008 until 2013, unless terminated at any time through a written notice by either Party submitted within 3 (three) months in advance.

Termination of this Arrangement shall not affect the validity or duration of any activities and/or contract made under the present Arrangement until the completion of such activities.

IN WITNESS WHEREOF, the undersigned, have signed the present Arrangement.

SIGNED in Beijing, People's Republic of China, on the Nineteenth of November in the year Two Thousand and Eight in duplicate, in Indonesian, Chinese, and English languages, all texts are equally authentic. In case of any divergence of interpretation, the English text shall prevail.

THE DIRECTORATE GENERAL

OF QUALITY IMPROVEMENT

FOR TEACHERS AND EDUCATION PERSONNEL

MINISTRY OF NATIONAL EDUCATION OF

THE REPUBLIC OF INDONESIA

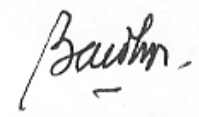

BAEDHOWI

DIRECTOR GENERAL
THE OFFICE OF CHINESE LANGUAGE COUNCIL INTERNATIONAL(HANBAN) OF THE PEOPLE'S REPUBLIC OF CHINA

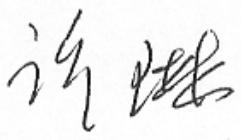

XU LIN

DIRECTOR GENERAL 


\author{
ADDENDUM OF ARRANGEMENT \\ BETWEEN \\ DIRECTORATE GENERAL OF QUALITY IMPROVEMENT \\ FOR TEACHERS AND EDUCATION PERSONNEL \\ MINISTRY OF NATIONAL EDUCATION OF \\ THE REPUBLIC OF INDONESIA \\ AND \\ THE OFFICE OF CHINESE LANGUAGE COUNCIL INTERNATIONAL \\ (HANBAN) OF \\ THE PEOPLE'S REPUBLIC OF CHINA \\ CONCERNING \\ CHINESE LANGUAGE TEACHING
}

This Addendum (additional conditions) of Arrangement between Directorate General of Quality Improvement for Teachers and Education Personnel, Ministry of National Education of the Republic of Indonesia and the Office of Chinese Language Council International (Hanban) of the People's Republic of China concerning Chinese Language Teaching, dated November 19, 2008, cannot be separated from the original Arrangement, has equal binding force. In case of similiar articles, this Addendum shall prevail.

\title{
I. STATUS OF CHINESE LANGUAGE TEACHER
}

The 'Chinese language teacher' stated in the Arrangement and the Addendum of Arrangement refers to 'volunteer Chinese teacher'.

\section{RIGHTS AND OBLIGATIONS OF THE PARTIES}

1. Chinese Side:

1.1 To provide every Chinese language teacher with part of monthly living allowance and cover the cost of one round-trip international travel annually;

1.2. To provide necessary teaching support materials.

2. Indonesian Side:

2.1. T o ensure punctual granting of one-year visas to the approved Chinese language teachers before their departure to Indonesia;

2.2. To assist the arrangement of stay permit, work permit, and single entry permit for every approved Chinese language teacher;

2.3. To designate the Chinese language teachers to the selected schools located in large or medium-sized cities agreed by the Chinese side. There should be no less than 100 students learning Chinese in each school;

2.4. To provide every Chinese language teacher with equipment and facilities necessary for teaching, such as computer, projector and internet access; 
2.5. To provide every Chinese language teacher with:

2.5.1 Independent house with basic living facilities including air-conditioner, parabola TV, telephone, kitchen, refrigerator, bathroom with toilet and shower, etc;

2.5.2 Part of monthly living allowance;

2.5.3 Transportation allowance for the work or provision of transportation means;

2.5.4 Travel allowance and Chinese newspapers and magazines;

2.5.5 Health insurance or payment for doctors, medicine and hospital, and to guarantee that every Chinese language teacher receives proper medical treatment promptly.

2.6. To assign contact persons for the Chinese language teachers and the host schools, to help the Chinese language teachers with their stay in Indonesia and to take tight security measures to ensure the safety of the Chinese language teachers.

Any dispute concerning the implementation of this Addendum of Arrangement shall be settled amicably through consultation or negotiations between the Parties.

Signed in Beijing, the People's Republic of China, on the Nineteenth of November in the year of Two Thousand and Eight in duplicate, in Indonesian, Chinese, and English languages, all texts are equally authentic. In case of any divergence of interpretation, the English text shall prevail.

THE DIRECTORATE GENERAL

OF QUALITY IMPROVEMENT

FOR TEACHERS AND EDUCATION PERSONNEL MINISTRY OF NATIONAL EDUCATION OF THE REPUBLIC OF INDONESIA

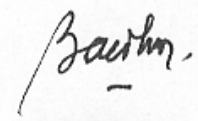

BAEDHOWI

DIRECTOR GENERAL
THE OFFICE OF CHINESE LANGUAGE COUNCIL INTERNATIONAL(HANBAN) OF THE PEOPLE'S REPUBLIC OF CHINA

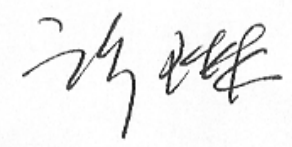

$\underline{X U \text { LIN }}$ DIRECTOR GENERAL 


\section{APPENDIX 2}

\section{Essence of Chinese Culiture} 文化集锥
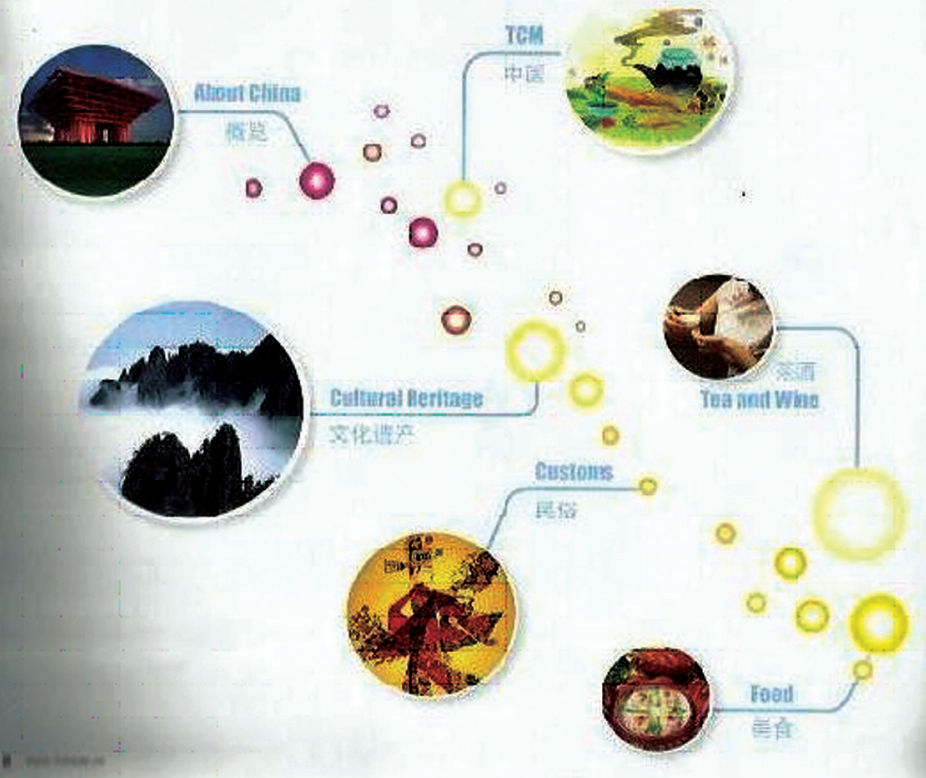

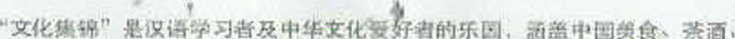

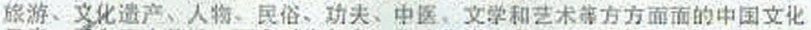

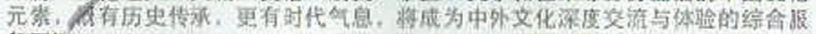
劳国地.

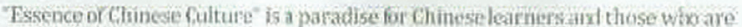

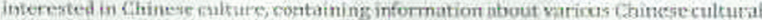
slementsinduding Chinese food, tea, witte, travel cultural heritages, people, customs, kìng Fin, traditional Clinese medicine, literatureand artsetc Inheriting historical culture and having conitemponary diaracteristics, this set tion will bea comprebensive service area for in-depth culturnl eschanecs and experiencrs hetweenchina and forcign countries.

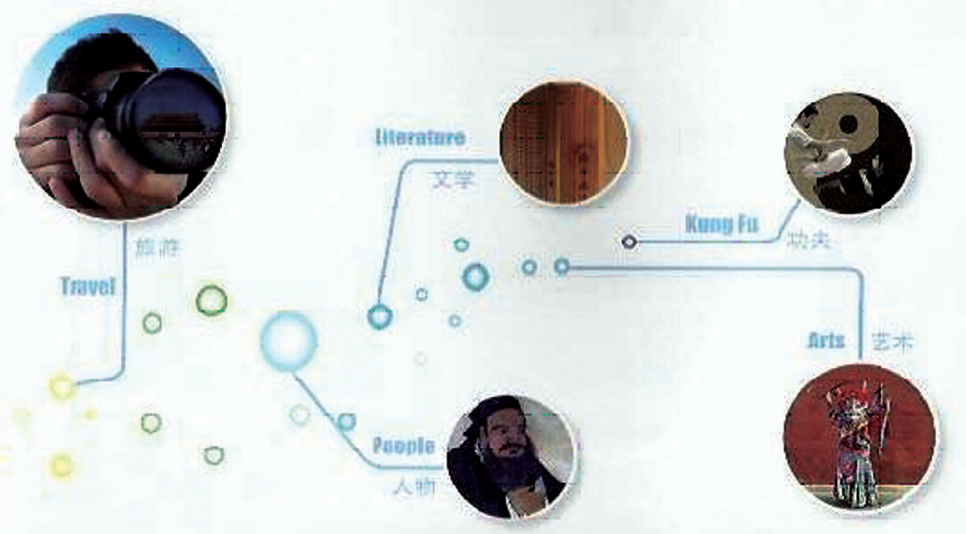

